\title{
Trophic interactions in the coastal ecosystem of Sri Lanka: An ECOPATH preliminary approach
}

\author{
S.S.K. Haputhantri ${ }^{a,}{ }^{*}$, M.C.S. Villanueva ${ }^{b}$, c and J. Moreau ${ }^{c}$
}

\begin{abstract}
${ }^{a}$ Marine Biological Resources Division, National Aquatic Resources Research and Development Agency (NARA), Crow Island, Colombo 15, Sri Lanka

bLaboratoire Ressources Halieutiques, IFREMER, Avenue du Général de Gaulle BP 32, 14520 Port-en-Bessin Huppain, France

'Laboratoire d'Agronomie, Environnement et Ecotoxicologie, INP/ENSAT, Avenue de l'Agrobiopole Auzeville Tolosane, BP 32607F, 31326 Castanet Tolosan Cedex, France
\end{abstract}

*: Corresponding author : S.S.K. Haputhantri, email address : sisirahaputhantri@yahoo.com

\begin{abstract}
:
This study attempts to assemble and summarize existing information in order to build a general representation of the trophic interactions within the shallow coastal ecosystem of Sri Lanka. A multispecific ecosystem-based approach on trophic relationships and their possible variations was performed using ECOPATH. Thirty-nine functional groups were considered representing all trophic levels in the food web.

Time-dynamic simulation was carried out using the ECOSIM routine to evaluate the impact of the 1998 El Niño event on key functional groups. Results show that the time needed for any impacted functional group to recover to its initial abundance increased with the trophic level. Two time-series data sets derived from commercial catch and effort statistics were used for validation of ECOSIM results. The EI Niño simulation results validated by the time-series data confirmed the ability of the proposed multispecies model to describe the sudden environmental changes.

Possible impacts due to increase of fishing effort were also simulated by separately considering frequently used fishing gears. The analysis revealed that small-mesh gillnet fishery operates independently from the other existing developing fisheries in the same area and can be managed accordingly.

Fishing-effort simulations suggest that the increase of fishing intensity by small-mesh gillnets would contribute to the decline of small pelagic catch. This was also found to influence the overall catch. The present level of exploitation of small pelagic fishery resources does not seem sustainable.
\end{abstract}

Keywords: trophic modelling; ECOPATH; ECOSIM; trophic level; feeding relationships; fisheries management; Indian Ocean; Sri Lanka 


\section{Introduction}

An ecosystem-based approach to fisheries is essential for the management of exploited species and for their long term sustainability (ICES, 2000; Garcia and Cochrane, 2005). Species in an ecosystem interact biologically and are interconnected through the food webs (Pascual and Dunne, 2006). Earlier practice of treating fish stocks as independent from one another when implementing management policies is being progressively replaced by this approach (Christensen and Pauly, 1993; ICES, 2000; Garcia and Cochrane, 2005). An obvious limitation of single from multispecies fisheries management is that it does not consider a global evaluation of changes in ecosystem structure and functions related to species interactions (Mace, 2001; Pikitch et al., 2004). In the ecosystem-based fisheries management, several factors affecting resource sustainability can be integrated. Interspecies interactions within an ecosystem, impacts of the massive climatic and environmental changes and the fishing impacts are just some of the critical factors that should be integrated in the formulation of management strategies (Browman et al., 2004; Pikitch et al., 2004). Worldwide, the capacity of coastal and marine ecosystems to produce fish to serve human interest is highly degraded by over fishing, trawling and loss of nursery areas (Pauly et al., 1998; McGlade et al., 2002). In Sri Lanka, exploitation of marine resources occurs all around the coast but is mainly confined 
61 to the narrow continental shelf, which rarely exceeds $40 \mathrm{~km}$ and averages around $22 \mathrm{~km}$ in width. The 62 total area of the shelf is about $30000 \mathrm{~km}^{2}$, which is around $6 \%$ of the total area of the Exclusive 63 Economic Zone (EEZ) of Sri Lanka. Coastal fishery from the seas off Sri Lanka (except in the northern 64 and eastern areas) is a proliferating activity, which targets particularly small pelagic species. This is basically due to the remarkable productivity and high accessibility of this zone and based on the recent government incentive to develop the coastal fishery sub-sector to alleviate the increasing level of unemployment. Fishing intensity had rapidly increased due to the motorization of boats and the introduction of synthetic materials for gillnet webbing after the 1950s (Dayaratne and Sivakumaran, 1994). The fisheries sector has become adversely affected by the influx of displaced personnel due to the civil war in the North and East of the island. Unemployed people were forced to consider fishing as an occupation and resulted to the war-torn northern and the eastern parts of the island. Disputes were further aggravated during the 1990s due to the successful experimental purse seining initially practised for capturing live bait for the pole-and-line fishery.

Biodiversity of the coastal ecosystem of Sri Lanka is very rich and includes various fish populations (De Bruin et al., 1995), similarly to most other tropical marine ecosystems (Burke et al., 2001; Rocha et al., 2005). However, individual contribution of most species to the total catch is very small. The coastal fish production is mainly dominated by clupeids and other small pelagic species which are exploited by small mesh gillnets (Dayaratne and Sivakumaran, 1994).

80

81 The complex food web of this coastal ecosystem and its functioning are basically unknown. Although 82 the biology and population dynamics of some key coastal species have been studied individually, providing estimations of population parameters, mortality, stock size and recruitment (Dayaratne, 1998; Karunasinghe and Wijeyaratne, 1998; Sanders et al., 2000, Jayawardane et al., 2002), these studies in themselves provide insufficient information to plan sustainable resource management for this ecosystem. Moreover, no attempt has been made to understand the population dynamics at an ecosystem level through trophic links.

The ECOPATH approach was designed exactly for the above purpose (Christensen and Pauly, 1993).

90 The advantage of this kind of model is that it provides an overview of the ecosystem's trophic state 
91 using few data requirements. Once constructed, the model can be updated and used to assess biomass response as a function of change, i.e. exploitation, climate change or degradation

93 (Christensen et al., 2005).

Massive climatic and environmental changes due to natural phenomena such as El Niño are frequently reported from many parts of the world (Kim and Kang, 2000; Pulwarty and Melis, 2001; Cubillos and Arcos, 2002; Rodríguez-Graña and Castro, 2003; Tam et al., 2006). Some of them have affected the different functional groups of marine ecosystems (Miller and Fluharty, 1992; Souter et al., 2000; Cubillos and Arcos, 2002; Tam et al., 2006).The ability to understand how climate will change from one year to the next will lead to better management of fisheries. The resource fluctuations induced by climate variability however make complex the fisheries management. Regardless, fish populations collapse due to the inability of the fishing industry to recover from over exploitation

103 (Forrester, 1997; http://www.csa.com/discoveryguides/archives/elnino.php). Fishery managements have to respond for minimizing those negative impacts by taking appropriate measures in resources exploitation.

106

The 1998 El Niño event which occurred in the Indian Ocean resulted to an elevation of sea surface temperature. Many coral reefs in the region have been affected with an extensive coral bleaching and subsequent mortality (Le Blanc, 1999). As a result, between 50 and $90 \%$ of the corals in the shallow seas off Sri Lanka were destroyed (Rajasuriya and Karunarathne, 2000). The biophysical and socio-

111 economic impacts on the coral reef associated fish population and dependents, particularly focusing

112 on vulnerable groups of the coastal human population, are now being studied. However, only few

113 studies have addressed the impact of the El Niño Southern Oscillation (ENSO) phenomenon on the 114 coastal fish communities. Le Blanc (1999) addressed the impact of this phenomenon on tuna fisheries.

116 The objectives of the present study were to assemble, integrate and summarize available information

117 to develop a comprehensive picture the Sri Lankan coastal ecosystem trophic structure and living 118 resources exploitation in the fisheries. The recent developments of the ECOPATH mass-balance 119 approach (Christensen and Pauly, 1992) were used as a modelling tool to develop a multispecific, 120 trophic model for the ecosystem considered. Time-dynamic analyses using the ECOSIM routine 
121 (Christensen et al., 2005) were also considered to evaluate possible impacts of increase in fishing

122 effort and the severe El Niño event of 1998 on key functional groups of the ecosystem.

123

124

2. Materials and Methods

125

126

2.1. The ECOPATH model and software

127

128

\subsubsection{Mass balance modelling}

129 The ECOPATH software (Polovina, 1984; Christensen and Pauly, 1993; 1996; Pauly et al., 2000;

130 Christensen et al., 2005; Pauly et al., 2000) was used to perform a mass-balance model. ECOPATH

131 production equation for any group ' $i$ ' can be written as:

132

133

$$
P_{i}=Y_{i}+B_{i} \cdot M 2_{i}+P_{i}\left(1-E E_{i}\right)
$$

134

135

where $P_{i}$ is its total production of $i, Y_{i}$ its yield or catch in weight, $B_{i}$ the biomass, $M 2_{i}$ is its total predation, $E_{i}$ the net migration (emigration - immigration), while $P_{i}\left(1-E E_{i}\right)$ is the 'other mortality'. $E E_{i}$ is the "ecotrophic efficiency", i.e., the proportion of the production of $i$ that is exported or consumed by the predators in the system.

139 The above equation can be re-expressed as:

140

141

$$
B_{i} \cdot(P / B)_{i} \cdot E E_{i}=Y_{i}+\sum_{j=1}^{n} B_{j} \cdot(Q / B)_{i} \cdot D C_{j i}
$$

142

143 Where $(P / B)_{i}$ is the production/biomass ratio usually assumed to be equal to total mortality $Z$ defined in

144 fisheries sciences (Allen, 1971; Lévêque et al.,1977), $(Q / B)_{i}$ is the consumption/biomass ratio, and $D C_{j i}$

145 is the fraction of prey $i$ in the average diet of predator $j$.

146

147 When the values for the parameters of the model are provided, ECOPATH estimates the missing

148 parameter for each group in the model e.g. the mean annual biomass, the annual biomass production,

149 the annual biomass consumption or ecotrophic efficiency for each of the groups in the ecosystem. 
152 Once an ECOPATH model is built, it can be used directly for simulation modelling using ECOSIM.

153 ECOPATH mass balance results are used here as input data for this trophodynamic simulation 154 modeling (Walters et al., 1997). The basic biomass dynamic differential equation in ECOSIM is given 155 by:

156

158

159

160

161

162

163

164

165

166

167

168

169

170

171

172

173

174

175

176

177

178

179

180

Where $d B_{i} / d t$ represents the growth rate of group $i$ in terms of its biomass, $f(B)$ is a function of $B_{i}$ if $i$ represents primary production. In other words, $M_{0}$ is for unaccounted mortality, $F_{i}$ is fishing mortality rate and $c_{i j}\left(B_{i}, B_{j}\right)$ is the function for predicting the amount of $i$ consumed by a predator $j$. ECOSIM solves the set of equations numerically.

\subsection{Model construction}

\subsubsection{Boundaries for the proposed ECOPATH model}

The proposed ecosystem model represents a part of the shallow coastal ecosystem of Sri Lanka in year 2000 from Chilaw up to Trincomalee (Fig.1). For the purpose of this analysis, the coastal zone has been defined to include the intertidal and subtidal areas on and above the continental shelf to about $20 \mathrm{~km}$ from the main shoreline (total area of around $14000 \mathrm{~km}^{2}$ ). Average Sea Surface Temperature (SST) is $28^{\circ} \mathrm{C}$.

\subsubsection{Identification of functional groups}

Fifty-eight fish species frequently reported in the fisheries data for the year 2000 were re-grouped into 29 fish functional groups (Table 1). Functional groups were categorized/grouped based on similarities in habitat, maximum body size, feeding habits, physiological behaviour and ecological distribution in order to obtain and keep homogeneous characteristics among the species within a group (Yodzis and Winemiller, 1999). For each group, whenever possible, a representative species was selected based on its importance in the fisheries and information availability. Shrimps, crabs and cephalopods which appear in the fisheries statistics were also incorporated. In addition, the following food sources for fish 
181 were considered: bivalves, annelids, other benthic invertebrates, zooplankton, phytoplankton, 182 phytobenthos and detritus.

183

184 As a general rule for every group, demographical parameters, diet composition, food consumption, 185 habitat and other information were obtained from the existing literature, with preference to local and 186 regional data. In the absence of this information, data from similar ecosystems were considered. 187 Fishbase (www.fishbase.org) (Fröese and Pauly, 2006) has also been utilized to bridge gaps whenever possible. For non-fish groups, data sources are summarized in table 2.

189

\subsubsection{Actual catch}

191 Annual yield (Table 3) was estimated from the National Aquatic Resources Research and Development Agency of Sri Lanka (NARA) fish landings survey data and from fish landing estimates of the Ministry of Fisheries and Aquatic Resources of Sri Lanka (MFAR). Data from NARA and MFAR were used to estimate monthly catches of most small pelagic species and demersal species, respectively. For each species, annual catch is calculated as:

196 Total annual catch $=$ mean catch in $\mathrm{kg}$ per craft $\times$ mean number of crafts operated per day $\times$ mean

197 number of fishing days per month $\times 12$ months

198 Annual yield for crabs is estimated based on export statistics (NARA, 2001).

199 The total estimated annual catch is 61,500 tons which was mainly captured by two categories of 200 fishing gears: small mesh gillnets (i.e. mesh size $6-38 \mathrm{~mm}$ ) and other gears for the multispecies 201 consideration. Input catch data were standardized by area.

\subsubsection{Basic parameters of fish}

\subsubsection{The Production/Biomass (P/B) ratio}

206 For this study, we assume that $P / B$ is equal to the total instantaneous mortality, $Z$, as indicated by 207 Allen (1971). Consequently, for commercially exploited stocks, this was calculated by obtaining the sum of the fishing $(F)$ and natural $(M)$ mortalities. $M$ was calculated using the empirical formula of Pauly (1980). 
212 This is the total mass per functional group expressed as $\mathrm{t}_{\mathrm{km}} \mathrm{km}^{-2}$. A variety of techniques have been 213 used to estimate this parameter. Except for halfbeaks and soles, biomass per habitat area was 214 estimated using the relationship:

215

$216 \quad B=Y / F$

218 where $Y$ is the annual yield and $F$ is the coefficient of the fishing mortality.

219 For halfbeaks and soles, biomass per habitat area was estimated using an EE value of 0.5 for 220 halfbeaks, which do not experience heavy predation, and an EE value of 0.95 for soles, which are 221 heavily predated by certain fish.

222

223 Biomasses for non-fish groups were not available except for shrimps. For shrimps, biomass was 224 estimated from the equation (4) using the data of Jayawardane et al (2002). Phytoplankton biomass 225 for the site considered is estimated at $2.625{\mathrm{t} . \mathrm{km}^{-2}}^{2}$ (Table 3). The Bay of Bengal large marine 226 ecosystem (LME) has a class II productivity level, moderately productive (150-300 gC.m². $\mathrm{yr}^{-1}$ ), based 227 on SeaWiFS global primary productivity. According to Dwivedi (1993), marshes and mangroves 228 contribute to the overall productivity of this LME. Phytoplankton biomass is based on estimations by 229 Pattiaratchi (2002).

\subsubsection{The relative food consumption (Q/B)}

232 For fish groups $Q / B$ ratios were computed using the predictive model of Palomares and Pauly (1998). 233 For other groups, $Q / B$ was estimated from the empirical relationship proposed by Palomares and 234 Pauly (1989). The aspect ratio of the caudal fin $(A)$, indicative of metabolic activity and expressed as 235 the ratio of the square of the height of the caudal fin and its surface area, is obtained mainly from 236 Fishbase (www.fishbase.org) (Fröese and Pauly, 2006).

238 The asymptotic weight $\left(W_{\infty}\right)$, which is required for both models (Palomares and Pauly, 1989; 1998), 239 was derived from the asymptotic length $\left(L_{\infty}\right)$. Length-weight $(L-W)$ relationships from Dayaratne (1998) 240 were considered for some fish groups such as sardines; herrings; pony fishes and flying fishes, 
Hirundichthys coromandelensis. For other groups, the $L-W$ relationships were based from Fishbase

242 (www.fishbase.org) (Fröese and Pauly, 2006).

\subsubsection{The diet composition of every group}

As indicated earlier, trophic interactions were poorly investigated in the coastal ecosystem of Sri Lanka. Only a few previous studies on feeding ecology have been carried out in this area (De Silva and Wijeyaratne, 1977 in Mohsin and Ambak, 1996). Due to the lack of available information on diet composition of groups considered, data were taken from Fishbase (www.fishbase.org) (Fröese and Pauly, 2006) and from the work of Mohsin and Ambak (1996).

When the diet of the predatory fish was not described, spatial distribution and size-range were used to predict potential prey/s (Pauly 1998; Blaber, 2000). The feeding matrix is provided in annex 1.

\subsection{Estimating unknown parameters and evaluating the model}

Basic estimations are independently made of missing parameters of ECOPATH functional groups, including estimations for trophic level $(T L)$ and omnivory index $(O S)$ of each group. The group-specific omnivory index $O /$ is computed as the variance of the TLs of each predator's prey groups (Christensen and Pauly, 1993) $O /$ varies from 0 to 1 , where a value close to 0 indicates high predatory specialization (feeding on one $T L$ only) and 1 indicates a maximum feeding versatility on several TLs.

Following Christensen et al. (2000) the pedigree of an ECOPATH input is here understood as a coded statement that categorizes data sources based on their type and the uncertainty associated with them. Based on the options selected for each parameter for each group, a pedigree index $P$ can be calculated for the whole ecosystem as the product of all the pedigree parameter specific indices and its scale varies between 0 and 1 .

\subsection{ECOSIM simulations}

269 In order to assess the possibility of over-fishing, simulations using ECOSIM were carried out by 270 increasing by two folds the fishing effort within the next ten years for small-mesh gillnets and other 
271 gears, first separately as suggested by Walters et al. (1997), and then together. Here, the vulnerability, 272 a parameter incorporated by Walters et al. (1997) and documented by Christensen et al. (2005) for a 273 proper use of ECOSIM expresses the mechanism of trophic flows control in the ecosystem. It ranges 274 from 0 (bottom up) to 1 (top down) (See Christensen et al., 2000 for more details). For preliminary 275 investigations, an intermediate default value of 0.3 was adopted for all groups as suggested by 276 Christensen et al. (2005). A Vulnerability Index (VI) of 0.2 as predators was only assigned to small 277 sized fish species, for zooplankton and benthic organisms, which might be directly influenced by food 278 availability at lower TLs.

279

280 In addition to these exercises, an attempt was made to assess the influence of an El Niño event to 281 depict changes in primary production and fish recruitment the one that occurred in 1998. It affects the ecosystem in two ways: modifications of the recruitment of fish and decrease of the primary production. A decrease of the primary production by 2 , which lasted three months (May-June), was simulated. This is a reasonable assumption, which corresponds to what happened in other marine ecosystems during a massive El Niño (http://www.csa.com/discoveryguides/archives/elnino.php). For clarity, the evolutionary trends of the biomass of few groups selected in various trophic levels (TL) were summarized. They are Phytoplankton (TL 1), Zooplankton (TL2), Herrings (TL 2.64) Sardines (TL 2.84 i.e. close to 3), Anchovies (TL 2.95 i.e. close to 3), Large tuna (TL 3.86 i.e. close to 4) (see below). For such a simulation, ECOSIM requires the fishing activity to remain constant.

\subsection{ECOSIM simulation on fishing effort impacts}

292 Two time series derived from commercial catch and effort statistics, obtained before, during and after 293 the El Niño were used for validation of ECOSIM results. Average monthly catch rates of Herring (catch 294 in $\mathrm{kg} \mathrm{boat}^{-1}$ day $^{-1}$ ) derived from the fisheries statistics collected from west to east of the ecosystem for 295 the Fibber Reinforced Plastic (FRP) boats during the period January 1998 - December 2001 were 296 plotted to observe their trends in abundance. It should be noted that Amblygaster sirm (the 297 representative species of the ECOPATH group Herring) is the key target species for this coastal 298 vessel. Moreover, the catch rates for the ECOPATH group of large tunas and king fish obtained from 299 January 1998 to December 2003 for a special category of coastal vessels (day boats, 3.5 tons with 300 inboard engine) from the west part of the ecosystem were also plotted. It should be noted that species 
represented by the ECOPATH group of large tunas and king fish are considerably exploited by these vessels. Moving average tool of Microsoft Excel software was employed to obtain smooth plots for monthly catch rates. For the validation of ECOSIM results, it was assumed that the catch rates derived

304 from commercial fisheries statistics reflect the species abundance (Bellido et al., 2001; Haputhantri 305 and Jayawardena, 2006).

306

\section{Results}

308 An estimated pedigree index of 0.587 conformed to the lower limit of overall quality of an Ecopath 309 model as discussed by Christensen et al. (2005).

\subsection{Basic estimations}

312 The basic inputs and estimated parameters are presented in Table 3. The estimated total fish biomass 313 was $5.101 \mathrm{t} \mathrm{km}^{-2}$ year $^{-1}$. EES computed for phytoplankton and detritus were very low.

Assuming that zooplankton is distributed homogeneously within the first 50 meters of the water column, $0.041 \mathrm{~g} \mathrm{fw} \cdot \mathrm{m}^{-3}$, it should be noted that the volumetric density of zooplankton is very low and this value appears to be close to several values available in Christensen and Pauly (1993).

Higher TLs (more than 3.6) were estimated for tunas and barracudas (Table 3). Important groups for 320 fisheries belong between TL2 and TL3, mainly small-sized species which mostly feed on zooplankton 321 and benthic organisms even as juveniles.

323 The data collected and assumptions made and integrated as basic inputs appear reasonable, 324 considering the results obtained for gross efficiency (GE) of each group. In particular, $G E$ is higher for 325 medium and large tunas than for small ones (Table 3) which is in agreement with differential feeding 326 habits related to maximum size. $P / Q$ for sardines is quite high due to an exceptionally high $P / B$ value, 327 whereas it is low for large barracudas. 
330 For several groups, the estimated EE values were higher than 0.9 (Table 3) meaning that these 331 groups are highly predated and exploited by fisheries. A particular emphasis has to be put on the 332 groups exploited by small mesh gillnets for which possible over fishing might be considered. The 333 assumption of high EES for invertebrate groups appears to be appropriate as they are highly 334 consumed as they constitute a high proportion of the diet composition of several groups (see annex 1)

335 The computed low EEs for both phytoplankton and detritus could presumably be attributed to absent 336 of typical primary consumers (except zooplankton) in the ecosystem. For other groups, the EE values computed by the model seem to be in an agreement with what is known both in terms of fishing 338 pressure and possibilities of predation.

339

340 The flow diagram of the ECOPATH model is shown in Fig. 2. The ecosystem is phytoplankton-based, 341 as $70.4 \%$ of the total food consumption comes from primary producers and only $29.6 \%$ originated 342 from detritus, a feature of relevance in deep water bodies (Christensen and Pauly, 1993). Most 343 primary production was consumed by the benthic organisms and zooplankton groups whereas the 344 dominant flow to detritus (about 80\% of the total) came from primary producers (TL1).

The $\mathrm{O} /$ of each group is also presented in Table 3. Higher $\mathrm{O} /$ was estimated for needlefish, sea catfish 347 and other carangids $(0.377,0.367$ and 0.332 respectively). High O/s reflect large feeding spectrum 348 and distribution in the ecosystem. The $\mathrm{O} /$ of shrimps and crabs were also exceptionally high. The TL 349 of catch is 2.88 whereas the GE of catch is 0.0042 .

350

351

352

353

354

355

356

357

358

\subsection{Fishing effort simulation results}

The outputs of the fishing effort simulations describe the situation of the ecosystem at the end of the three distinct exercises in terms of biomass and possible catch (Tables 4 to 6). When the small-mesh gillnets is considered, results show a biomass decline of several targeted species at various extents; for example the catch of sardines would collapse. Catches would increase to various levels for most other groups except yellowstripes, the abundance of which would decrease, most likely due to unavailability of their preys (Table 4). 
Increasing the fishing effort of other gears would, most likely, not have any negative affect to the biomass of small fishes since these are mainly caught by small-mesh gillnets. Catch of some less predated fish groups are less impacted (Table 5). Moreover, the decrease in abundance of principal groups predated by tuna and barracuda increased following the stock collapse of these predators.

The increase in fishing effort for both fishing activities led to the collapse of the sardine stocks and fishery. Similar trends were observed for the three tuna groups. Herring and other clupeids stocks seem to decrease as a response to increasing fishing pressure. Thryssa and Anchovies biomass and catch would increase substantially.

An increase in fishing activity of all combined gears seemed to affect biomass of functional groups captured by the different gears. In terms of catch, small mesh-gillnet fishing seems to contribute largely to the overall decline in catch. Fishing activities by other gears increases the total catch of targeted species to about $31 \%$ (Table 5). Finally, if both fishing activities were developed simultaneously to the same extent, this would result to a decline (about 18\%) of small-mesh gillnets catches while increasing catches from other gears to about 25\% (Table 6).

\subsection{El Niño simulation results}

377 From El Niño simulation results (Fig. 3), groups belonging to the lower TLs appear to be strongly influenced by phytoplankton abundance variations. The Zooplankton group seems immediately affected whereas other groups would affect with some delay. The delay would increase whereas the magnitude of variations decreases with increasing TL. A minimum lag time of one year was observed for trends to be stabilised. The time needed for any group to get back to its initial abundance increased with the TL. The depletion of large tuna and other predators (not displayed on Fig. 3) might have contributed to the temporary very high abundance of the clupeids, which is simulated one year after the El Niño event

\subsection{Model validation results}

387 The plots of the derived monthly mean catch in $\mathrm{kg}$ per boat per day (CPUE) for two of the ECOPATH functional groups are shown in the Fig. 4. The figure also indicates the trends in abundance of two 
groups estimated by the moving average method. The catch rates of Herring had been on a declining trend since the early months of 1999 (Fig. 4a). This was observed until end of 2000. However, this group managed to recover after 2000. The catch rates of other ECOPATH groups (large tuna and kingfish) have considerably been affected from 1999 - 2002 and gradually recovered since 2003 (Fig. 4b). Accordingly, the ECOSIM simulation results were in accordance with the actual trends in the abundance of two ECOPATH groups represented by the monthly catch rates.

\section{Discussion}

There are few pitfalls in the ECOPATH/ECOSIM approach. ECOSIM can produce misleading predictions. Erroneous predictions usually result from bad estimates or errors of omission for a few key parameters such as B, P/B and Q/B (Christensen et al., 2005). Moreover, incorrect assessments of predation impacts for prey that are rare in predator diets, underestimates of predation vulnerabilities and temporal variation in species-specific habitat had also been previously noted as some factors that could be influenced for final results.

The main limitation of the present model is related to the steady-state consideration, as most of the input data referred to different time periods. This ecosystem has experienced environmental fluctuations over the studied period such as the massive El Niño of 1998: Therefore, the steady-state assumption might not reflect environmental conditions closed to the reality. Moreover, the ecosystem is not completely closed and many groups such as larger fishes (tunas) are not restricted to the area.

As noted above, the major challenge for this multispecies modelling was the lack of studies on the 411 feeding ecology of the functional groups considered. Therefore, further investigation should be carried 412 out on this topic which should be considered as one of the key priority objective in this research area.

413 To improve the quality of the presented model, it would therefore be necessary to improve the quality 414 of the catch landing statistics under the above-mentioned catch monitoring programmes in order to 415 obtain more precise estimations for a multispecies approach.

416 Preparation of the feeding matrix for this ECOPATH model was a difficult task since lack of previous 417 studies on feeding ecology in relation to this ecosystem. Most of the qualitative data provided by outside studies were converted into a quantitative form for preparation of the feeding matrix. As the 
model consists of many groups (39 groups), the feeding matrix contains some low percentages. In

420 fact, these values are hard to determine from field data. This nature too might substantially influence

421 for the final result.

422 The TL of catch is 2.88 due to the relative importance of intermediate TLs. The GE of catch is in 423 agreement with earlier findings for various marine environments (Christensen and Pauly, 1993), but 424 much lower than that observed in the San Miguel Bay, Philippines: 0.016 (Bundy and Pauly, 2001). By 425 contrast, West African ecosystems display much lower values of the GE of the catch: less than 0.001 426 (Chavance et al., 2004).

427 The estimated total fish biomass was in fact quite low compared to some tropical littoral marine 428 ecosystems documented in West Africa by (Palomares et al., 2003) in which estimated biomasses 429 vary from 16.1 to $27.2 \mathrm{t} \mathrm{km}^{-2}$. The fish biomass of $5.1 \mathrm{t} \mathrm{km}^{-2}$ in the littoral waters of Sri Lanka is similar 430 to what was computed by Christensen (1998).

For ECOSIM simulations, the choice of the values for the vulnerability parameter is very important 433 since simulations are very sensitive to this parameter. We adopted default values which compromise between top down and bottom up regulations of the food web and might not be too far from the reality.

435 A further increase in the fishing effort of small-mesh gillnet fishery would seriously affect the small 436 pelagic fish populations, mainly sardines, in terms of biomass and catches. Sardines play a vital role contributing to a significant wasp-waist control in the ecosystem. They are key species in the transferring energy from primary and secondary productions to higher TLs.

439

440 Within the ECOSIM simulations, a special attempt was made to understand the possible impacts of a 441 sudden environmental change which could be similar to the massive El Niño event experienced in 442 1998. The ENSO phenomenon takes place every three to seven years and each time substantial 443 impacts to fisheries have been observed (http://www.csa.com/discoveryguides/archives/elnino.php; 444 Le Blanc, 1999; Loukos et al., 2003). This phenomenon has been observed responsible for drastic 445 reduction in the primary production due to the lack cold nutrient-rich water, which becomes limiting 446 (Loukos et al., 2003; Roessing et al., 2004). An increase in sea surface temperature levels can alter 
ecological behaviours (i.e. migration patterns, increased mortalities, change in spawning season, etc) of some groups living resources and as a consequence lead to change in ecosystem structure. This was already observed in 1997-98 in California where the distribution, abundance and catch of market squid declined (National Assessment Synthesis Team -US Global Change Research Programme, $4512000 ;$ http://www.usgcrp.gov/usgcrp/Library/nationalassessment/overviewcoastal.htm) following the ENSO phenomenon. Other unusual co-occurring changes observed were widespread sea lion pup mortality in California, catches of warm-water marlin in the usually frigid waters off the Washington State and poor salmon returns in Bristol Bay, Alaska.

455

Roessing et al. (2004) examined the global climate change-related effects like El Niño on tropical fishes by looking at comparatively well-studied tropical coral reef ecosystems and their fish communities. They selected only the coral reef communities since previous physiological studies of other tropical fishes were found to be comparatively few. It concluded that adverse impacts on coral reef (coral bleaching and the loss of reef complexity, etc.) after severe climate-related effects could be the main causes of considerable reduction in terms of abundance and the biodiversity of several invertebrates and fishes. Coral reef communities seem to be among the first groups to show signs of such adverse effects probably due to weak trophic links even if these groups are less exploited in the fisheries (Dulvy et al. 2004). It has also been observed in some cases that increases in temperature could affect immune system function and decrease fecundity in coral reef fishes (Cubillos and Arcos, 2002).

467

In West Africa, the El Niño effect had completely changed the hydrology of several aquatic ecosystems. Sine Saloum, as an example, had evolved into an inverse hypersaline estuary following this event. Although it did not have considerable detrimental effects on the system's species richness, inhabiting species, mainly true estuarine, were considerably replaced by marine-estuarine species nor in some life-history traits of some fish species (Panfili et al., 2004).

474 Recruitment in clupeid fish species is known to be highly seasonal and variable (Karunasinghe and 475 Wijeyaratne, 1998). Low biomass in late 1998 may be due to recruitment failure caused by El Niño. 476 The El Niño effect in 1998 might have appeared with a certain time lag in small pelagic fishes. As 
sardines and herrings have high turn-over rates (i.e., high $P / B$ ratio), the El Niño effect might have affected the landings within a short time lag.

479

Fish populations may need many years to recover after an ENSO phenomenon, as observed from our ECOSIM simulations. This might be due not only to the trophic link re-structuring cumulated with high fishing mortality of fished groups. Understanding such responses from different communities experiencing similar environmental changes seem to be essential to improve management decisions for sustainable utilisation of the fishery resources. But, time lag events could be tested from ECOSIM routine, which allows for the simulation of the ecosystem and therefore, provides a basis for the consideration of it as a dynamic system.

Time dynamic simulation has been an effective tool in describing the El Niño simulation results and proved useful in depicting ecosystem response to sudden environmental change. However, as noted above, there was some disagreement concerning the recovery time of affected populations between the ECOSIM predictions and the field observations. The delays in the actual recovery time of the affected populations could presumably be attributed to other factors related to significant adaptive response/s in some aggregated groups that may be "masked" due to limited information. Moreover, the catch rates derived from commercial fisheries data may not reflect correctly the abundance of the concerned fish groups.

Although it is impossible to predict the effects of global warming on the frequency of El Niño events, all indications seem to be that they are becoming stronger, more common, and are no longer disappearing completely. Some climate model experiments suggest an increase in El Niño frequency,

500 linked to a future greenhouse warming (Timmermann et al. 1999). On the other hand, a different 501 physical model leads to strong upwelling in the eastern equatorial Pacific that could weaken the warming there, thereby strengthen equatorial winds, causing more upwelling and a net cooling in the eastern Pacific (Cane et al. 1997).

504

505 The fishing industry of Sri Lanka was severely affected owing to the surprised tsunami disaster in $26^{\text {th }}$

506 December 2004. Heavy damages were especially reported from the fishing crafts operated in the 
shallow coastal waters. This was greatly contributed to ease the fishing pressure on the coastal waters. Small pelagic fish landing statistics in 2005 indicated an increase trend in the catch per boat compared to previous years. On the other hand, habitat destruction by the tsunami has affected to reduce the abundance, particularly species associated with coral substrates such as butterflyfish

511 (Chaetodontidae), gobies (Gobiidae) and wrasses (Labridae) (Rajasuriya et al., 2005;

512 http://www.nara.ac.Ik/RAP). In addition to the above, ground level species of the food web such as 513 phytoplankton and zooplanktons might have considerably affected during the tsunami. This would gradually affect to the higher TLs as previously observed in El Niño simulation.

The above results furthermore suggest that there is not enough evidence to accept that the current fishing practices of small pelagic species and factors other than fishery (depletion of the stocks due to other reasons) might have produced some severe changes in the fish resources availability resulting in a time limited but apparent over fishing. Therefore, more cautions should be made to keep the present levels or possibly of a lower level of exploitations of small pelagic fishes. Moreover, there are some possibilities to increase the exploitation from other gears and to target large predatory fishes, which are more abundant in deeper waters outside the present ecosystem.

\section{Conclusion}

The ECOPATH model built up to describe the trophic relationships in the coastal ecosystem of Sri Lanka helps to understand the general dynamic of this ecosystem. Moreover, quantitative and

527 qualitative information provided by the model are in agreement with studies for similar ecosystems. This multispecific approach furthermore provides informative explanations of some incidents which took place during the past.

During a natural event such as El Niño, there is a high risk to affect the marine food web of this ecosystem. Therefore, additional care must be taken into consideration on sudden crashes of the fish populations after such an event. Recovery time of the displaced populations after a sudden environmental change could vary due to several reasons. Continuation of the exploitations furthermore by fishing during such a crucial stage might lead to a total collapse of the resources. 
537 It was noted that there are few possibilities to increase the current exploitation of large pelagic fishery

538 resources. However, it is advisable to provide subsidies for few fishermen who are currently engaged

539 in coastal small scale gillnet fishery, and to direct them to the exploitation of large pelagic fish and

540 thereby reduce the fishing pressure on small pelagic fishes. Sri Lanka has not yet been able to make

541 effective use of the high value tuna and other resources in the deep sea areas as well as in the high seas due to the non-availability of fishing vessels with the requisite capabilities.

543

\section{Acknowledgements}

545

546 We are grateful to Professor U. S. Amarasinghe of University of Kelaniya, Sri Lanka, Professor S. De

547 Silva of Deakin University, Australia, Dr. Aruna Jayawardane and Mr. Tinil Fernando of National

548 Aquatic Resources Research and Development Agency (NARA) of Sri Lanka for their invaluable

549 supports to complete this study successfully. Special thank should go to Mr J.K. Rajapakshe of NARA

550 for preparing the map of the studied ecosystem. The first author would like to thank the Asian

551 Development Bank for granting him a scholarship to follow a PhD at École Nationale Supérieure 552 Agronomique de Toulouse, France.

553

554

555

556

557

558

559

560

561

562

563

564

565 


\section{References}

Abarca-Arenas, L.G., Valero-Pacheco, E., 1993. Toward a trophic model of Tamiahua, a coastal Iagoon in Mexico,. In: Christensen, V., Pauly, D. (Eds.), Trophic Models of Aquatic Ecosystems, ICLARM Conference Proceedings 26, ICLARM/ICES/DANIDA, Manila, Philippines, pp.181-185.

Allen, K.R., 1971. Relation between production and biomass. Journal of the Fisheries Research Board of Canada 28, 1573-1581.

Arreguín-Sánchez, F., Valero-Pacheco, E., Chavez, E.A., 1993a. A trophic box model of the coastal Models of Aquatic Ecosystems, ICLARM Conference Proceedings 26, ICLARM/ICES/DANIDA,

Arreguín-Sánchez, F., Seijo, J.C., Valero-Pacheco, E., 1993b. An application of ECOPATH II to the north continental shelf ecosystem of Yucatan, Mexico. In: Christensen, V., Pauly, D. (Eds.), Trophic Models of Aquatic Ecosystems, ICLARM Conference Proceedings 26, ICLARM/ICES/DANIDA, Manila, Philippines, pp. 269-278.

584

Bay of Bengal Programme (BOBP), 1987. Final report of the Working Group on the tunas in the EEZ's 586 of Maldives and Sri Lanka. In Indo-Pacific Tuna Collective volume of working documents. Expert Consultation on Stock Assessment of Tunas in the Indian Ocean. Colombo, 4-8 December 1986. IPTP, Colombo, Sri Lanka. pp. 281-293.

589

Bellido, J.M., Pierce, G.J., Wang, J., 2001. Modelling intra-annual variation in abundance of Squid Loligo forbesi in Scottish waters using generalized additive models. Fisheries Research 52, 23-39.

593 Blaber, S.J.M., 2000. Tropical estuarine fishes: Ecology, exploitation and conservation. Blackwell 594 Science Ltd., Oxford. 372 pp. 
Browman, H.I., Cury, P.M., Hilborn, R., Jennings, S., Lotze, H.K., Mace, P.M., Murawski, S., Pauly, D., Sissenwine, M., Stergiou, K.I., Zeller, D., 2004. Perspectives on ecosystem-based approaches to the management of marine resources. Marine Ecology Progress Series 274, 269-303.

599

600

Bundy, A., Pauly, D., 2001. Selective harvesting by small-scale fisheries: ecosystem analysis of San Miguel Bay, Philippines. Fisheries Research 53, 263-281.

602

603

Burke, L., Kura, Y., Kassem, K., Revenga, C., Spalding, M., McAllister, D., 2001. Pilot analysis of 604 Global ecosystems: Coastal Ecosystems. Washinton DC, World Resources Institute: 77 pp.

605

Cane, M. A., Clement, A. C., Kaplan, A., Kushnir Y., Pozdnyakov, D., Seager, R., Zebiak S. E.,

Chavance, P., Ba, M., Gascuel, D., Vakily, M. and Pauly, D., editors. (2004) Pêcheries maritimes, écosystèmes et sociétés en Afrique de l'Ouest : un demi-siècle de changement. Actes du symposium international, Dakar - Sénégal, 24-28 Juin 2002. Office des publications officielles des communautés Européennes, XXXVI, collection des rapports de recherche halieutique ACP-UE 15, pp. 532.

613

614 Chavez, E.A., Garduno, M., Arreguin-Sanchez., F., 1993. Trophic dynamic structure of Celestun

615 Lagoon, Southern Gulf of Mexico. In: Christensen, V., Pauly, D. (Ed.), Trophic Models of Aquatic 616 Ecosystems, ICLARM Conference Proceedings 26, ICLARM/ICES/DANIDA, Manila, Philippines, pp. $617 \quad 186-192$.

618

619 Christensen V.1998 Fishery induced changes in a marine ecosystem, insight from models of the gulf 620 of Thailand. Journal of Fish Biology 53 A: 128-142.

621

622 Christensen, V., Pauly, D., 1992. ECOPATH II - A software for balancing steady-state models and 623 calculating network characteristics. Ecological Modelling 61, 169-185.

624 
625 Christensen, V., Pauly, D., 1993. Trophic Models of Aquatic Ecosystems. ICLARM Conf. Proc. 26: 390

$626 \mathrm{pp}$.

627

628 Christensen, V., Pauly, D., 1996. Ecological modelling for all. Naga. 19, 25-26.

629

630 Christensen, V., Walters, C.J., Pauly, D., 2000. Ecopath with Ecosim Version 4, Help system@.

631 University of British Columbia, Fisheries Centre, Vancouver, Canada and ICLARM, Penang, Malaysia.

632

633 Christensen, V., Walters, C.J., Pauly, D., 2005. Ecopath with Ecosim Version 5, Help system@.

634 University of British Columbia, Fisheries Centre, Vancouver, Canada.

635

636 Cubillos, L.A., Arcos, D.F., 2002. Recruitment of common sardine (Strangomera bentincki) and 637 anchovy (Engraulis ringens) off central-south Chile in the 1990s and the impact of the 1997-1998 El 638 Niño. Aquatic Living Resources 15: 87-94.

639

640 Dayaratne, P., 1998. Review of Resource assessment information on small pelagic fish stocks in 641 coastal marine waters of Sri Lanka. Sri Lanka Journal of Aquatic Science 3, 1-10.

642

643 Dayaratne, P., Sivakumaran, K.P. 1994. Biosocieconomics of fishing for small pelagics along the 644 southwest coast of Sri Lanka. National Aquatic Resources Agency Report BOBP/WP/96, Colombo, Sri 645 Lanka, $21 \mathrm{pp}$.

646

647 De Bruin, G.H.P., Russell, B.C., Bogusch A., 1995. FAO species identification field guide for fishery 648 purposes. The marine fishery resources of Sri Lanka. FAO, Rome, 400 pp.

649

650 Dulvy, N.K., Polunin, N.V.C., Mill, A.C., Graham, N.A.J., 2004. Size structural change in lightly 651 exploited coral reef fish communities: Evidence of weak indirect links. Canadian Journal of Fisheries 652 and Aquatic Science 61, 466-475.

653 
654 Dwiponggo, A., Hariati, T., Banon, S., Palomares, M.L., Pauly, D., 1986. Growth, mortality and 655 recruitment of commercially important fishes and penaeid shrimps in Indonesian waters. ICLARM 656 Technical Reports 17. Research Institute for Marine Fisheries, Jakarta, Indonesia and International 657 Center for Living Aquatic Resources Management, Manila, Philippines. 91 pp.

658

659 Dwivedi, S.N. 1993. Long-Term Variability in the Food Chains, Biomass Yield, and Ocenaography of 660 the Bay of Bengal Ecosystem, pp. 43-52. In K. Sherman, L.M. Alexander and B.D. Gold (Eds.), Large 661 Marine Ecosystems: Stress, Mitigation, and Sustainability, American Association for the Advancement 662 of Science, Washington, D.C.

663

664 Forrester, A.L., 1997. The effects of El Niño on Marine Life. WWW Page, घ 665 http://www.csa.com/discoveryguides/archives/elnino.php.

666

667 Fröese, R. Binohlan C. 2000. Empirical relationships to estimate asymptotic length, length-at-first 668 maturity and yield at maximum yield-per-recruitment in fishes, with a simple method to evaluate length 669 frequency data. Journal of Fish Biology 56, 758-773.

670

671 Fröese, R., Pauly, D. (Ed.), 2006. Fishbase. World Wide Web electronic publication. WWW Page, ש 672 www.fishbase.org.

673

674 Garcia, S.M., Cochrane, K.L., 2005. Ecosystem appraoch to fisheries: A review of implementation 675 guidelines. ICES Journal of Marine Science 62, 311-318.

676

677 Haputhantri, S.S.K., Jayawardena P.A.A.T., 2006. Predictive models for penaeid shrimp abundance in 678 the seas off Negombo and Hendala, Sri Lanka. Fisheries Research 77, $34-44$.

679

680 ICES, 2000. Ecosystem effects of fishing. Proceedings of an ICES/SCOR symposium held in 681 Montpellier, France, 16-19 March 1999. ICES Journal of Marine Science 57, 465 - 792.

682 
Irvine, K., Waya, R., 1999. Spatial and temporal patterns of zooplankton standing biomass and production in Lake Malawi. Hydrobiologia 407, 191-205.

685

Jayawardane, P. A. A. T., McLusky, D. S., Tytler, P. 2002. Estimation of population parameters and stock assessment of Penaeus indicus (H. Milne Edwards) in the western coastal waters of Sri Lanka. Asian Fisheries Science 15, 155-166.

689 Karunasinghe, W.P.N., Wijeyaratne, M.J.S., 1998. Reproductive biology of the trenched sardine Amblygaster sirm (Walbaum) from the western coastal waters of Sri Lanka. Ceylon Journal of Science (Bioscience) 25, 5-51.

692

Kim, S., Kang, S., 2000. Ecological variations and El Niño effects off the southern coast of the Korean Peninsula during the last three decades. Fisheries Oceanography 9, 239-247.

695

Le Blanc, J.-L. 1999. What do we know about El Nino in the Indian Ocean ?: A toolbox for fisheries biologists.IOTC Proceedings on the $7^{\text {th }}$ Expert Consultation on Indian Ocean Tunas, Victoria, Seychelles, 9-14 November 1998. pp 106-117.

699

Lévêque, C., Durand, J.R., Ecoutin, J.M., 1977. Relations entre le rapport P/B et la longévité des organismes. Cahiers ORSTOM, Série Hydrobiologie 11, 17-31. pelamis) habitat from a global warming scenario: modelling approach and preliminary results. Fisheries Oceanography 12, 474-482.

Mace, P. M., 2001. A new role for MSY in single-species and ecosystem approaches to fisheries stock assessment and management. Fish and fisheries 2, 2-32.

McGlade, J. M., Cury, P., Koranteng, K. A., Hardman-Mountford, N. J., 2002. The Gulf of Guinea large marine ecosystem: environmental forcing and sustainable development of marine resources. Elsevier Science B.V., Amsterdam, 392 pp. 
714 Mohsin, A.K.M., Ambak, M.A., 1996. Marine fishes \& fisheries of Malaysia and neighbouring countries. 715 Universiti Pertanian Malaysia Press, Malaysia. 742 pp.

Miller, K. A.; Fluharty, D. L., 1992. El Nino and variability in the northeast Pacific salmon fishery. In: 718 Glantz, M.H. (Ed), Climate Variability, Climate Change and Fisheries. Cambridge University Press, pp. 49-88.

NARA, 2001. Sri Lanka Fishery Year Book. National Aquatic Resources Research and Development Agency. Colombo 15, Sri Lanka. 77pp.

National Assessment Synthesis Team - US Global Change Research Programme, 2000. Climate change impacts on the United States. The potential consequences of climate variability and change.

WWW

Page,

727 http://www.usgcrp.gov/usgcrp/Library/nationalassessment/overviewcoastal.htm.

Palomares, M.L.D., Pauly, D., 1989. A multiple regression model for predicting the food consumption of marine fish populations. Journal of Marine and Freshwater Research 40, 259-273.

Palomares, M.L., Pauly, D., 1998. Predicting food consumption of fish populations as functions of mortality, food type, morphometrics, temperature and salinity. Journal of Marine and Freshwater Research 49(5), 447-453.

Panfili, J., Mbow, A., Durand, J.-D., Diop, K., Diouf, K., Thior, D., Ndiaye, P, Laë, R., 2004. Influence of salinity on the Ife-history traits of the bonga shad (Ethmalosa fimbriata, Pisces, Clupeidae): comparison between the Gambia and Saloum estuaries. Marine Ecology Progress Series 270, 241257.

Pascual, M., Dunne, J.A., 2006. Ecological networks: Linking structure to dynamics in food webs. Oxford University Press, New York, 386 pp. 
744 Pattiaratchi, C., 2002. Physical Oceanography: its uses in climate and fisheries in Sri Lanka. In : C. 745 Pattiaratchi (Ed.). Oceanography \& Hydrography for exploration \& exploitation of maritime 746 environment. National Aquatic Resources Research and Development Agency, Colombo, Sri Lanka, 747 pp. 1-13.

Pauly, D., 1980. On the interrelationships between natural mortality, growth parameters and mean environmental temperature in 175 fish stocks. Journal du Conseil International pour l'Exploration de la Mer 39, 175-192.

752

Pauly, D., 1998. Tropical fishes: patterns and propensities. Journal of Fish Biology 53, 1-17.

Pauly, D., Christensen, V., Dalsgaard, J., Froese R., Torres, F. Jr., 1998. Fishing down marine food webs. Science $279,860-863$.

Pauly, D., Christensen, V., Walters, C.J., 2000. Ecopath, Ecosim and Ecospace as tools for evaluating ecosystem impact of fisheries. ICES Journal of Marine Science 57, 697-706.

760

Pikitch, E.K., Santora, C., Babcock, E.A., Bakun, A., Bonfil, R., Conover, D.O., Dayton, P., Doukakis,

Polovina, J.J., 1984. Model of a coral reef ecosystems I. The ECOPATH model and its application to 766 French Frigate Shoals. Coral Reefs 3, 1-11.

768 Pulwarty, R.S., Melis, T.S., 2001. Climate extremes and adaptive management on the Colorado River: 769 Lessons from the 1997-1998 ENSO event. Journal of Environmental Management 63, 307-324. 
Rajasuriya, A., Karunarathne, C., 2000. Post-bleaching status of the coral reefs of Sri Lanka. In: Souter, D., Obura, D., Linden, O. (Ed.), Coral Reef Degradation in the Indian Ocean, Status Report 2000. CORDIO, SAREC Marine Science Programme, pp. 54-63.

Rajasuriya, A., Karunarathne, C., Tamelander, J., Perera, N., Fernando, M., 2005. Rapid Assessment of Tsunami Damage to Coral Reefs in Sri Lanka. WWW Page, as www.nara.ac.Ik/RAP.

Rocha, L.A., Robertson, D.R., Roman, J., Bowen, B.W., 2005. Ecological cpeciation in tropical reef

Rodríguez-Graña, L., Castro, L.R. 2003. Ichthyoplankton distribution off the Peninsula de Mejillones, Chile (23. S, 71.W), under variable hydrographic conditions during the austral summer and winter of the 1997 El Niño. Hydrobiologia 501, 59-73.

Roessing, J.M., Woodley, C.M., Cech, J. J. Jr., Hansen, L. J., 2004. Effects of global climate change on marine and estuarine fishes and fisheries. Review of Fish Biology and Fisheries 14, 251-275.

Sanders, M., Jayawardena, A., Ediriweera, S., 2000. Preliminary assessment for the shrimp fisheries of the Negombo Lagoon (Sri Lanka). FAO Fisheries Circular No, 958. Rome, FAO, 98 pp.

Sarvala J., Salonen, K., Järvinen, M., Aro, E., Huttula, T., Kotilainen, P., Kurki, H., Langenberg, V., Mannini, P., Peltonen, A., Plisnier, P.D., Ilppo Vourinen, Mölsä, H., Lindqvist, O., 1999. Trophic structure of Lake Tanganyika: carbon flows in the pelagic food web. Hydrobiologia 407, 149-173.

Siriwardena, P.P.G.S.N., 1986. Milkfish pen culture in Sri Lankan lagoons. In Maclean, J. L., Dizon, L.B., Hosillos, L.V. (Eds.). The First Asian Fisheries Forum. Asian Fisheries Society, Manila. pp. 8892. corseletted frigate mackerel, Auxis thazard (Lacépède) and Auxis rochei (Risso) around Ceylon. In 
801 Proceedings Symposium on Living Resources of Seas Around India. Special Publication. Central 802 Marine Fisheries Research Institute, Cochin. pp. 537-547.

803

804 Souter, D., Obura, D., Linden, O., 2000. Coral Reef Degradation in the Indian Ocean, Status Report 805 2000. CORDIO, SAREC Marine Science Programme, 284 pp.

806

807 Tam, J., Purca, S., Duarte, L.O., Blaskovic, V., Espinoza, P., 2006. Changes in the diet of hake 808 associated with El Niño 1997-1998 in the Northern Humboldt current ecosystem. Advances in 809 Geosciences 6, 63-67.

810

811 Timmermann, A., Oberhuber, J., Bacher, A., Esch, M., Latif, M., Roeckner. E., 1999. Increased El

812 Niño Frequency in a Climate Model Forced by Future Greenhouse Warming. Nature, 398, 694-696.

813

814 Vega-Cendejas, M.E., Arreguin-Sanchez, F., Hernandez, M., 1993. Trophic fluxes on Campeche 815 Bank, Mexico, In: Christensen, V., Pauly, D. (Ed.), Trophic Models of Aquatic Ecosystems, ICLARM 816 Conference Proceedings 26, ICLARM/ICES/DANIDA, Manila, Philippines, pp. 206-213.

817

818 Walters, C., Christensen, V., Pauly, D., 1997. Structuring dynamic models of exploited ecosystems 819 from trophic mass balanced assessments. Review of Fish Biology and Fisheries 7, 139-172.

820

821 Wijeyaratne, M.J.S., Costa, H.H., 1987. Fishery, seasonal abundance and mortality of grey mullets 822 (Pisces: Mugilidae) in Negombo Lagoon, Sri Lanka. Journal of Applied Ichthyology 3, 115-118.

823

824 Yodzis, P., Winemiller, K. O. 1999. In search of operational trophospecies in a tropical aquatic food 825 web. Oïkos 87, 327-340. 
Table 1. Growth and mortality parameters of the selected ECOPATH functional fish groups with the selected representative species in the coastal ecosystem of Sri Lanka.

\begin{tabular}{|c|c|c|c|c|c|c|}
\hline $\begin{array}{c}\text { ECOPATH } \\
\text { Group }\end{array}$ & Representative species & $\begin{array}{c}\mathrm{L}_{\infty} \\
(\mathbf{c m} \mathrm{TL})\end{array}$ & $\begin{array}{c}\mathrm{K} \\
\left(\text { year }^{-1}\right)\end{array}$ & $\begin{array}{l}Z(P / B) \\
\left(\text { year }^{-1}\right)\end{array}$ & $\begin{array}{c}M \\
\left(\text { year }^{-1}\right)\end{array}$ & $\begin{array}{c}\mathbf{F} \\
\left(\text { year }^{-1}\right)\end{array}$ \\
\hline Sea catfish & Arius bilineatus & $64.3^{\mathrm{a}}$ & $0.15^{\mathrm{b}}$ & $0.98^{\mathrm{C}}$ & $0.42^{d}$ & $0.56^{\mathrm{e}}$ \\
\hline Needlefish & Strongylura leiura & $73.0^{\mathrm{a}}$ & $0.12^{\mathrm{b}}$ & $0.50^{f}$ & $0.35^{d}$ & $0.15^{\mathrm{e}}$ \\
\hline Pomfrets \& Torp & Parastromateus niger & $39.4^{a}$ & $0.60^{a}$ & $2.50^{g}$ & $1.18^{\mathrm{d}}$ & $1.32^{\mathrm{e}}$ \\
\hline Bigeye scad & Selar crumenophthalmus & $34.8^{\mathrm{h}}$ & $0.50^{h}$ & $1.60^{\mathrm{h}}$ & $1.09^{d}$ & $0.51^{\mathrm{e}}$ \\
\hline Yellowstripe & Selaroides leptolepis & $23.0^{\mathrm{a}}$ & $1.15^{\mathrm{a}}$ & $4.26^{i}$ & $2.10^{d}$ & $2.16^{\mathrm{e}}$ \\
\hline Other Carangids & Carangoides malabaricus & $29.0^{\mathrm{a}}$ & $0.96^{\mathrm{a}}$ & $2.00^{f}$ & $1.75^{d}$ & $0.25^{\mathrm{e}}$ \\
\hline Milk fish & Chanos chanos & $47.9^{j}$ & $0.30^{k}$ & $0.81^{\prime}$ & $0.71^{\mathrm{e}}$ & $0.10^{\prime}$ \\
\hline Wolf-herrings & Chirocentrus dorab & $117.9^{\mathrm{a}}$ & $0.10^{\prime}$ & $0.35^{f}$ & $0.28^{d}$ & $0.07^{\mathrm{e}}$ \\
\hline Sardines & Sardinella gibbosa & $17.0^{\mathrm{h}}$ & $2.20^{h}$ & $10.30^{h}$ & $3.60^{d}$ & $6.70^{\mathrm{e}}$ \\
\hline Herrings & Amblygaster sirm & $24.1^{\mathrm{h}}$ & $1.52^{h}$ & $3.65^{h}$ & $2.49^{d}$ & $1.16^{\mathrm{e}}$ \\
\hline Other Clupeids & Hilsa kelee & $21.5^{\mathrm{a}}$ & $1.10^{\mathrm{a}}$ & $3.09^{i}$ & $2.08^{d}$ & $1.01^{\mathrm{e}}$ \\
\hline Dolphinfishes & Coryphaena hippurus & $177.7^{\mathrm{a}}$ & $0.05^{1}$ & $0.25^{f}$ & $0.15^{d}$ & $0.10^{\mathrm{e}}$ \\
\hline Thryssa sp. & Thryssa setirostris & $22.8^{a}$ & $1.30^{\mathrm{b}}$ & $2.45^{f}$ & $2.29^{d}$ & $0.16^{\mathrm{e}}$ \\
\hline Anchovies & Stolephorus heterolobus & $8.6^{\mathrm{h}}$ & $4.02^{h}$ & $7.57^{\mathrm{h}}$ & $6.48^{d}$ & $1.09^{\mathrm{e}}$ \\
\hline Flyingfishes & Hirundichthys oxycephalus & $28.5^{h}$ & $1.10^{\mathrm{h}}$ & $3.09^{h}$ & $1.93^{d}$ & $1.16^{\mathrm{e}}$ \\
\hline Halfbeaks & Rhynchorhamphus malabaricus & $36.6^{a}$ & NA & $1.92^{\mathrm{C}}$ & $0.96^{d}$ & $0.96^{\mathrm{e}}$ \\
\hline False trevallie & Lactarius lactarius & $27.0^{\mathrm{a}}$ & $0.63^{a}$ & $1.61^{\prime}$ & $1.39^{d}$ & $0.25^{\prime}$ \\
\hline Ponyfishes & Leiognathus brevirostris & $13.8^{a}$ & $0.90^{\mathrm{a}}$ & $4.40^{\mathrm{a}}$ & $2.10^{d}$ & $2.30^{\mathrm{e}}$ \\
\hline Mugilids & Mugil cephalus & $89.7^{\mathrm{m}}$ & $0.09^{\mathrm{m}}$ & $1.10^{\mathrm{n}}$ & $0.51^{d}$ & $0.59^{e}$ \\
\hline Terapontids & Terapon theraps & $34.0^{\mathrm{a}}$ & $0.61^{a}$ & $1.39^{\prime}$ & $1.24^{d}$ & $0.15^{\mathrm{e}}$ \\
\hline Ribbon fish & Lepturacanthus savala & $108.0^{\mathrm{a}}$ & $0.75^{a}$ & $1.41^{f}$ & $1.03^{d}$ & $0.38^{\mathrm{e}}$ \\
\hline Drums & Otolithes ruber & $45.9^{a}$ & $0.32^{a}$ & $1.00^{\prime}$ & $0.78^{d}$ & $0.22^{\mathrm{e}}$ \\
\hline Indian mackerel & Rastrelliger kanagurta & $36.0^{\mathrm{h}}$ & $1.70^{\mathrm{h}}$ & $3.99^{h}$ & $2.48^{d}$ & $1.51^{\mathrm{e}}$ \\
\hline Small Tunas & Auxis thazard thazard & $63.7^{\circ}$ & $0.83^{\circ}$ & $2.84^{i}$ & $1.28^{d}$ & $1.56^{\mathrm{e}}$ \\
\hline Medium Tunas & Katsuwonus pelamis & $85.0^{p}$ & $0.44^{p}$ & $2.46^{\mathrm{c}}$ & $0.78^{d}$ & $1.68^{\mathrm{e}}$ \\
\hline Large Tunas \& Kingfish & Scomberomorus commerson & $146.0^{\mathrm{h}}$ & $0.37^{\mathrm{h}}$ & $1.49^{i}$ & $0.60^{d}$ & $0.89^{\mathrm{e}}$ \\
\hline Soles & Euryglossa orientalis & $33.0^{\mathrm{a}}$ & NA & $1.2^{1}$ & $0.97^{q}$ & $0.23^{e}$ \\
\hline Large Barracuda & Sphyraena jello & $148.0^{\mathrm{a}}$ & $0.10^{a}$ & $0.50^{\prime}$ & $0.25^{d}$ & $0.25^{\mathrm{e}}$ \\
\hline Small barracuda & Sphyraena obtusata & $39.5^{\mathrm{a}}$ & $0.62^{a}$ & $3.37^{c}$ & $1.23^{d}$ & $2.14^{\mathrm{e}}$ \\
\hline
\end{tabular}

a. Fröese and Pauly (2006);

b. Estimated value with reference to $L_{\infty}$;

c. Computed value indirectly after the computation of Q/B from the predictive model of Palomares and Pauly (1989) (see the text below) by assuming a reasonable value of gross food-conversion efficiency GE (defined by $G E=P / Q)$ ) by referring to the group's diet composition $(D C)$ as suggested by Christensen and Pauly (1993).

d. Pauly (1980) (temperature for the study area was considered as $28^{\circ} \mathrm{C}$ );

e. Estimated value from the relationship $Z=F+M$;

f. Lévêque et al (1977);

g. An average of several $Z$ values for fish of the same family mainly Pampus species (Dwiponggo et al., 1986 and Dadzie et al 2003 in press);

h. Dayaratne (1998);

i. Moshin and Ambak (1996);

j. Siriwardena (1986);

k. A computed value using auximetric grid in fishbase (Fröese and Pauly, 2006);

I. A suggested value;

m. Wijeyaratne and Costa (1987);

n. An average value from two out side studies ((Abarca-Arenas and Valero-Pacheco, 1993 and Chavez et al, 1993);

o. Sivasubramaniam (1973);

p. BOBP (1987);

q. Value computed based on empirical relation of Fröese and Binohlan (2000). 
Table 2. Sources of the data (mainly $P / B$ and $Q / B$ ) of non fish groups

\begin{tabular}{|c|c|c|c|}
\hline Group & $P / B$ & $Q / B$ & $E E$ \\
\hline Shrimps (Penaeus indicus) & Jayawardane (2001) & A value set for $P / Q=0.20$ & Computed by ECOPATH \\
\hline Crabs: & Abarca-Arenas and Valero-Pacheco (1993) & Arreguín-Sánchez et al.(1993a) & Value was fixed \\
\hline Cephalopods & Christensen and Pauly (1993). & Christensen and Pauly (1993). & A fixed value \\
\hline Molluscs & Chavez et al. (1993) & Vega-Cendejas et al. (1993). & A fixed value based on substantial predation \\
\hline Annelids/Polychaetes & Arreguín-Sánchez et al, (1993a, b). & Arreguín-Sánchez et al. (1993a, b). & A fixed value based on substantial predation \\
\hline Zoobenthos & Chavez et al. (1993). & Chavez et al. (1993). & $\begin{array}{l}\text { A fixed value based on substantial fish and } \\
\text { shrimp predation }\end{array}$ \\
\hline Zooplankton & $\begin{array}{l}\text { Irvine and Waya, (1999) Sarvala et al. } \\
\text { (1999) }\end{array}$ & $\begin{array}{l}\text { Irvine and Waya, (1999) Sarvala et al., } \\
(1999) \text {; Christensen et al. (2005) }\end{array}$ & $\begin{array}{l}\text { A fixed value based on substantial juvenile fish } \\
\text { predation }\end{array}$ \\
\hline Phytoplankton & Pattiaratchi (2002). & --- & Biomass was available \\
\hline Phytobenthos & Christensen and Pauly, (1993) & --- & A fixed value because of high predation \\
\hline
\end{tabular}


Table 3. Input values and estimated parameters (in brackets) for the coastal ECOPATH model of Sri Lanka. TL is the trophic level, $B$ is Biomass, $\mathrm{P} / \mathrm{B}$ is production rate, $\mathrm{Q} / \mathrm{B}$ is the consumption rate, $\mathrm{P} / \mathrm{Q}$ is production per consumption ratio, $E E$ is the ecotrophic efficiency and $O /$ is the omnivory index.

\begin{tabular}{|c|c|c|c|c|c|c|c|c|c|}
\hline $\begin{array}{l}\text { ECOPATH } \\
\text { Group }\end{array}$ & TL & $\begin{array}{l}\text { Catch (t } \\
\text { Gillnets }\end{array}$ & $\begin{array}{l}\left.m^{-2} \text { year }^{-1}\right) \\
\text { Other gears }\end{array}$ & $\begin{array}{c}B \\
\left(\mathrm{t} \mathrm{km}^{-2}\right)\end{array}$ & $\begin{array}{c}\text { P/B } \\
\left(\text { year }^{-1}\right)\end{array}$ & $\begin{array}{c}\text { Q/B } \\
\left(\text { year }^{-1}\right)\end{array}$ & PIQ & EE & OI \\
\hline Large tunas & (3.86) & & 0.154 & 0.173 & 1.49 & 7.77 & $(0.19)$ & $(0.67)$ & $(0.206)$ \\
\hline Medium tunas & (3.83) & & 0.013 & 0.008 & 2.46 & 12.29 & $(0.20)$ & $(0.77)$ & $(0.227)$ \\
\hline Small barracudas & (3.80) & 0.0035 & 0.032 & 0.016 & 3.37 & 13.48 & $(0.25)$ & (0.81) & $(0.205)$ \\
\hline Small tunas & (3.78) & 0.0009 & 0.008 & 0.006 & 2.84 & 18.85 & $(0.15)$ & (0.93) & $(0.223)$ \\
\hline $\begin{array}{l}\text { Large } \\
\text { barracudas }\end{array}$ & $(3.66)$ & & 0.105 & 0.428 & 0.50 & 5.49 & $(0.09)$ & (0.68) & $(0.167)$ \\
\hline Wolf-herrings & (3.58) & & 0.022 & 0.314 & 0.35 & 6.84 & $(0.05)$ & $(0.94)$ & $(0.209)$ \\
\hline Neddlefish & (3.54) & 0.0025 & 0.011 & 0.085 & 0.50 & 8.22 & (0.06) & $(0.48)$ & (0.377) \\
\hline Other carangids & (3.48) & & 0.220 & 0.879 & 2.00 & 17.43 & $(0.12)$ & (0.79) & $(0.332)$ \\
\hline Pomfrets, Torps & (3.41) & 0.006 & 0.064 & 0.051 & 2.50 & 15.70 & (0.16) & $(0.90)$ & (0.286) \\
\hline False trevallie & (3.38) & & 0.013 & 0.054 & 1.61 & 15.45 & $(0.10)$ & (0.93) & $(0.235)$ \\
\hline Yellowstripe & (3.29) & 0.0158 & 0.002 & 0.008 & 4.26 & 23.10 & $(0.18)$ & $(0.96)$ & (0.170) \\
\hline Dolphinfishes & (3.27) & & 0.018 & 0.180 & 0.25 & 3.67 & $(0.07)$ & (0.69) & $(0.205)$ \\
\hline Cephalopods & (3.22) & & 0.033 & $(2.750)$ & 3.10 & 12.00 & $(0.26)$ & 0.95 & (0.143) \\
\hline Sea cat fish & (3.11) & & 0.053 & 0.098 & 0.98 & 6.53 & $(0.15)$ & $(0.64)$ & $(0.367)$ \\
\hline Ribbonfish & (3.07) & & 0.075 & 0.196 & 1.41 & 6.18 & $(0.23)$ & $(0.50)$ & $(0.238)$ \\
\hline Ponyfishes & (3.06) & 0.0211 & 0.032 & 0.023 & 4.40 & 24.12 & $(0.18)$ & $(0.82)$ & (0.098) \\
\hline Soles & (3.06) & & 0.0184 & $(0.122)$ & 1.20 & 11.05 & (0.11) & 0.95 & (0.001) \\
\hline Indian mackerel & (3.05) & & 0.062 & 0.041 & 3.99 & 20.88 & $(0.19)$ & $(0.96)$ & $(0.000)$ \\
\hline Terapontids & (2.96) & & 0.004 & 0.040 & 1.39 & 12.58 & (0.11) & (0.84) & (0.105) \\
\hline Anchovies & (2.95) & 0.204 & 0.068 & 0.250 & 7.57 & 40.69 & (0.19) & (0.89) & $(0.100)$ \\
\hline Drums & (2.95) & & 0.026 & 0.120 & 1.00 & 8.48 & (0.12) & $(0.85)$ & (0.114) \\
\hline Other Clupeids & (2.88) & 0.206 & 0.0228 & 0.226 & 3.09 & 22.31 & (0.14) & (0.95) & (0.198) \\
\hline Sardines & $(2.84)$ & 1.385 & 0.073 & 0.218 & 10.30 & 34.02 & $(0.30)$ & (0.91) & (0.176) \\
\hline Thrissa spp & $(2.74)$ & 0.0724 & 0.024 & 0.612 & 2.45 & 18.56 & $(0.13)$ & (0.93) & $(0.233)$ \\
\hline Herrings & (2.64) & 0.668 & 0.035 & 0.606 & 3.65 & 23.31 & $(0.16)$ & (0.93) & $(0.260)$ \\
\hline Crabs & (2.64) & & 0.100 & (1.938) & 2.50 & 8.50 & $(0.29)$ & 0.95 & $(0.261)$ \\
\hline Flying fishes & $(2.53)$ & & 0.013 & 0.012 & 3.09 & 26.34 & $(0.12)$ & (0.89) & $(0.277)$ \\
\hline Milk fish & $(2.49)$ & 0.0011 & 0.003 & 0.040 & 0.81 & 37.75 & $(0.02)$ & (0.54) & $(0.275)$ \\
\hline Shrimps & (2.32) & & 0.266 & 0.102 & 5.28 & 26.40 & $(0.20)$ & (0.93) & (0.233) \\
\hline Bigeye scad & $(2.20)$ & 0.0329 & 0.099 & 0.257 & 1.60 & 32.93 & $(0.05)$ & $(0.74)$ & (0.210) \\
\hline Halfbeaks & (2.18) & 0.00219 & 0.007 & $(0.030)$ & 2.68 & 53.66 & $(0.05)$ & 0.50 & (0.156) \\
\hline Mugilids & (2.13) & & 0.004 & 0.008 & 1.10 & 20.36 & $(0.05)$ & $(0.67)$ & $(0.117)$ \\
\hline Annelids & $(2.05)$ & & & $(0.780)$ & 4.60 & 25.00 & $(0.18)$ & 0.95 & $(0.053)$ \\
\hline Zoobenthos & (2.05) & & & (5.559) & 10.00 & 50.00 & $(0.20)$ & 0.95 & (0.053) \\
\hline Zooplankton & (2.05) & & & (2.039) & 30.00 & 150.00 & $(0.20)$ & 0.95 & $(0.053)$ \\
\hline Molluscs & $(2.00)$ & & & (3.488) & 2.50 & 9.30 & $(0.27)$ & 0.95 & $(0.000)$ \\
\hline Phytoplankton & $(1.00)$ & & & 2.625 & 365.00 & - & - & $(0.33)$ & \\
\hline Phytobenthos & $(1.00)$ & & & (11.477) & 12.50 & - & - & 0.95 & \\
\hline Detritus & $(1.00)$ & & & 10.0 & 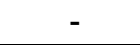 & - & - & $(0.23)$ & $(0.271)$ \\
\hline
\end{tabular}


Table 4. ECOSIM simulation results for the small mesh gillnets (key groups are in bold). OB is the original biomass, FB is the final biomass, OY is the original yield and FY is the final yield.

\begin{tabular}{|c|c|c|c|c|c|c|}
\hline Group name & OB & FB & FB/OB & OY & FY & FYIOY \\
\hline Large tunas & 0.173 & 0.167 & 0.97 & 0.154 & 0.149 & 0.97 \\
\hline Medium tunas & 0.008 & 0.007 & 0.87 & 0.013 & 0.011 & 0.87 \\
\hline Small barracuda & 0.016 & 0.011 & 0.68 & 0.036 & 0.026 & 0.73 \\
\hline Small tunas & 0.006 & 0.005 & 0.85 & 0.009 & 0.008 & 0.91 \\
\hline Large barracuda & 0.428 & 0.392 & 0.92 & 0.105 & 0.096 & 0.92 \\
\hline Wolf-herings & 0.314 & 0.242 & 0.77 & 0.022 & 0.017 & 0.77 \\
\hline Neddlefish & 0.085 & 0.075 & 0.88 & 0.014 & 0.014 & 1.00 \\
\hline Other carangids & 0.879 & 0.911 & 1.04 & 0.220 & 0.228 & 1.04 \\
\hline Pomfrets, Torps & 0.051 & 0.045 & 0.89 & 0.070 & 0.066 & 0.95 \\
\hline False trevallie & 0.054 & 0.06 & 1.12 & 0.013 & 0.015 & 1.12 \\
\hline Yellowstrip & 0.008 & 0.002 & 0.21 & 0.018 & 0.006 & 0.35 \\
\hline Dolphinfishes & 0.18 & 0.186 & 1.03 & 0.018 & 0.019 & 1.03 \\
\hline Cephalopods & 2.75 & 2.988 & 1.09 & 0.033 & 0.036 & 1.09 \\
\hline Sea cat fish & 0.098 & 0.100 & 1.02 & 0.053 & 0.054 & 1.02 \\
\hline Ribbonfish & 0.196 & 0.22 & 1.12 & 0.075 & 0.084 & 1.12 \\
\hline Ponyfishes & 0.023 & 0.016 & 0.71 & 0.054 & 0.050 & 0.92 \\
\hline Soles & 0.122 & 0.129 & 1.06 & 0.019 & 0.020 & 1.06 \\
\hline Indian mackerel & 0.041 & 0.047 & 1.16 & 0.062 & 0.072 & 1.16 \\
\hline Terapontids & 0.04 & 0.046 & 1.16 & 0.004 & 0.005 & 1.16 \\
\hline Anchovies & 0.249 & 0.26 & 1.05 & 0.283 & 0.464 & 1.64 \\
\hline Drums & 0.12 & 0.125 & 1.04 & 0.026 & 0.027 & 1.04 \\
\hline Other Clupeids & 0.224 & 0.16 & 0.72 & 0.238 & 0.285 & 1.2 \\
\hline Sardines & 0.209 & 0.028 & 0.13 & 1.473 & 0.336 & 0.23 \\
\hline Thrissa spp & 0.611 & 0.632 & 1.03 & 0.316 & 0.386 & 1.22 \\
\hline Herrings & 0.6 & 0.456 & 0.76 & 0.731 & 0.953 & 1.3 \\
\hline Crabs & 1.938 & 1.970 & 1.02 & 0.100 & 0.102 & 1.02 \\
\hline Flying fishes & 0.012 & 0.013 & 1.10 & 0.013 & 0.014 & 1.10 \\
\hline Milk fish & 0.040 & 0.039 & 0.99 & 0.004 & 0.005 & 1.19 \\
\hline Shrimps & 0.102 & 0.102 & 1.00 & 0.266 & 0.267 & 1.00 \\
\hline Bigeye scad & 0.257 & 0.231 & 0.90 & 0.134 & 0.144 & 1.08 \\
\hline Halfbeaks & 0.030 & 0.030 & 0.99 & 0.009 & 0.011 & 1.17 \\
\hline Mugilids & 0.008 & 0.010 & 1.27 & 0.004 & 0.005 & 1.27 \\
\hline Annelids & 0.78 & 0.789 & 1.01 & & & \\
\hline Zoobenthos & 5.562 & 5.503 & 0.99 & & & \\
\hline Zooplankton & 2.044 & 2.28 & 1.12 & & & \\
\hline Molluscs & 3.49 & 3.664 & 1.05 & & & \\
\hline Phytoplankton & 2.625 & 2.556 & 0.97 & & & \\
\hline Phytobenthos & 11.473 & 11.311 & 0.99 & & & \\
\hline Detritus & 9.299 & 9.092 & 0.98 & & & \\
\hline Small mesh gillnets & & & & 2.696 & 2.165 & 0.8 \\
\hline Other gears & & & & 1.892 & 1.807 & 0.95 \\
\hline Total & 45.145 & 44.904 & 0.99 & 4.588 & 3.972 & 0.87 \\
\hline
\end{tabular}


Table 5. ECOSIM simulation results for "other gears" (key groups are in bold). OB is the original biomass, $\mathrm{FB}$ is the final biomass, $\mathrm{OY}$ is the original yield and $\mathrm{FY}$ is the final yield.

\begin{tabular}{|c|c|c|c|c|c|c|}
\hline Group name & OB & FB & FB/O B & OY & FY & FYIOY \\
\hline Large tunas & 0.172 & 0.049 & 0.29 & 0.159 & 0.082 & 0.52 \\
\hline Medium tunas & 0.008 & 0.001 & 0.09 & 0.013 & 0.002 & 0.16 \\
\hline Small barracuda & 0.016 & 0.002 & 0.1 & 0.036 & 0.006 & 0.18 \\
\hline Small tunas & 0.006 & 0.002 & 0.31 & 0.009 & 0.005 & 0.53 \\
\hline Large barracuda & 0.427 & 0.301 & 0.7 & 0.109 & 0.138 & 1.26 \\
\hline Wolf-herings & 0.314 & 0.394 & 1.26 & 0.023 & 0.052 & 2.25 \\
\hline Neddlefish & 0.085 & 0.064 & 0.76 & 0.014 & 0.017 & 1.25 \\
\hline Other carangids & 0.877 & 0.900 & 1.03 & 0.228 & 0.420 & 1.84 \\
\hline Pomfrets, Torps & 0.05 & 0.013 & 0.25 & 0.072 & 0.031 & 0.43 \\
\hline False trevallie & 0.054 & 0.083 & 1.55 & 0.014 & 0.037 & 2.78 \\
\hline Yellowstripe & 0.008 & 0.011 & 1.36 & 0.018 & 0.027 & 1.49 \\
\hline Dolphinfishes & 0.180 & 0.137 & 0.76 & 0.019 & 0.025 & 1.36 \\
\hline Cephalopods & 2.750 & 2.779 & 1.01 & 0.034 & 0.062 & 1.81 \\
\hline Sea cat fish & 0.098 & 0.034 & 0.35 & 0.055 & 0.035 & 0.63 \\
\hline Ribbonfish & 0.195 & 0.135 & 0.69 & 0.078 & 0.096 & 1.24 \\
\hline Ponyfishes & 0.023 & 0.007 & 0.29 & 0.054 & 0.023 & 0.43 \\
\hline Soles & 0.122 & 0.116 & 0.95 & 0.019 & 0.033 & 1.70 \\
\hline Indian mackerel & 0.041 & 0.027 & 0.67 & 0.064 & 0.076 & 1.20 \\
\hline Terapontids & 0.040 & 0.058 & 1.45 & 0.004 & 0.011 & 2.61 \\
\hline Anchovies & 0.250 & 0.290 & 1.16 & 0.275 & 0.385 & 1.40 \\
\hline Drums & 0.120 & 0.146 & 1.22 & 0.027 & 0.059 & 2.18 \\
\hline Other Clupeids & 0.226 & 0.246 & 1.09 & 0.230 & 0.271 & 1.18 \\
\hline Sardines & 0.218 & 0.208 & 0.96 & 1.460 & 1.453 & 1.00 \\
\hline Thrissa spp & 0.610 & 0.680 & 1.11 & 0.321 & 0.578 & 1.8 \\
\hline Herrings & 0.606 & 0.651 & 1.07 & 0.704 & 0.788 & 1.12 \\
\hline Crabs & 1.937 & 1.872 & 0.97 & 0.104 & 0.180 & 1.73 \\
\hline Flying fishes & 0.012 & 0.011 & 0.95 & 0.013 & 0.023 & 1.71 \\
\hline Milk fish & 0.040 & 0.045 & 1.11 & 0.004 & 0.007 & 1.77 \\
\hline Shrimps & 0.100 & 0.019 & 0.19 & 0.272 & 0.094 & 0.34 \\
\hline Bigeye scad & 0.256 & 0.208 & 0.81 & 0.135 & 0.176 & 1.30 \\
\hline Halfbeaks & 0.030 & 0.040 & 1.32 & 0.009 & 0.020 & 2.12 \\
\hline Mugilids & 0.008 & 0.003 & 0.38 & 0.004 & 0.003 & 0.67 \\
\hline Annelids & 0.780 & 0.817 & 1.05 & & & \\
\hline Zoobenthos & 5.561 & 5.568 & 1.00 & & & \\
\hline Zooplankton & 2.042 & 2.024 & 0.99 & & & \\
\hline Molluscs & 3.488 & 3.432 & 0.98 & & & \\
\hline Phytoplankton & 2.625 & 2.630 & 1.00 & & & \\
\hline Phytobenthos & 11.475 & 11.459 & 1.00 & & & \\
\hline Detritus & 9.300 & 9.325 & 1.00 & & & \\
\hline Small mesh gillnets & & & & 2.620 & 2.645 & 1.01 \\
\hline Other gears & & & & 1.962 & 2.572 & 1.31 \\
\hline Total & 45.149 & 44.787 & 0.99 & 4.582 & 5.217 & 1.14 \\
\hline
\end{tabular}


Table 6. ECOSIM simulation results for combined gears (key groups are in bold). OB is the original biomass, $\mathrm{FB}$ is the final biomass, OY is the original yield and FY is the final yield.

\begin{tabular}{|c|c|c|c|c|c|c|}
\hline Group name & OB & FB & $\mathrm{FB} / \mathrm{OB}$ & OY & FY & FYIOY \\
\hline Large tunas & 0.172 & 0.043 & 0.25 & 0.159 & 0.072 & 0.45 \\
\hline Medium tunas & 0.008 & 0 & 0.05 & 0.013 & 0.001 & 0.10 \\
\hline Small barracuda & 0.016 & 0 & 0.02 & 0.036 & 0.002 & 0.04 \\
\hline Small tunas & 0.006 & 0.001 & 0.18 & 0.009 & 0.003 & 0.32 \\
\hline Large barracuda & 0.427 & 0.267 & 0.63 & 0.109 & 0.125 & 1.15 \\
\hline Wolf-herrings & 0.314 & 0.319 & 1.02 & 0.023 & 0.043 & 1.86 \\
\hline Neddlefish & 0.085 & 0.054 & 0.64 & 0.014 & 0.016 & 1.17 \\
\hline Other carangids & 0.877 & 0.926 & 1.06 & 0.229 & 0.442 & 1.93 \\
\hline Pomfrets, Torps & 0.050 & 0.008 & 0.17 & 0.072 & 0.022 & 0.30 \\
\hline False trevallie & 0.054 & 0.092 & 1.71 & 0.014 & 0.042 & 3.13 \\
\hline Yellowstripe & 0.008 & 0.003 & 0.33 & 0.018 & 0.011 & 0.59 \\
\hline Dolphinfishes & 0.180 & 0.139 & 0.77 & 0.019 & 0.026 & 1.41 \\
\hline Cephalopods & 2.751 & 3.043 & 1.11 & 0.034 & 0.07 & 2.02 \\
\hline Sea cat fish & 0.098 & 0.033 & 0.34 & 0.055 & 0.034 & 0.62 \\
\hline Ribbonfish & 0.195 & 0.152 & 0.78 & 0.078 & 0.111 & 1.42 \\
\hline Ponyfishes & 0.023 & 0.002 & 0.08 & 0.054 & 0.008 & 0.14 \\
\hline Soles & 0.122 & 0.125 & 1.02 & 0.019 & 0.036 & 1.87 \\
\hline Indian mackerels & 0.041 & 0.032 & 0.79 & 0.064 & 0.092 & 1.44 \\
\hline Terapontids & 0.040 & 0.065 & 1.63 & 0.004 & 0.012 & 2.99 \\
\hline Anchovies & 0.249 & 0.303 & 1.22 & 0.283 & 0.631 & 2.23 \\
\hline Drums & 0.120 & 0.152 & 1.27 & 0.027 & 0.063 & 2.32 \\
\hline Other Clupeids & 0.224 & 0.172 & 0.76 & 0.237 & 0.331 & 1.40 \\
\hline Sardines & 0.211 & 0.015 & 0.07 & 1.470 & 0.188 & 0.13 \\
\hline Thrissa spp & 0.610 & 0.698 & 1.14 & 0.324 & 0.679 & 2.09 \\
\hline Herrings & 0.601 & 0.481 & 0.80 & 0.726 & 1.062 & 1.46 \\
\hline Crabs & 1.938 & 1.909 & 0.99 & 0.104 & 0.188 & 1.80 \\
\hline Flying fishes & 0.012 & 0.012 & 1.05 & 0.013 & 0.026 & 1.92 \\
\hline Milk fish & 0.040 & 0.044 & 1.11 & 0.004 & 0.009 & 2.02 \\
\hline Shrimps & 0.100 & 0.017 & 0.17 & 0.272 & 0.084 & 0.31 \\
\hline Bigeye scad & 0.256 & 0.175 & 0.68 & 0.137 & 0.171 & 1.25 \\
\hline Halfbeaks & 0.030 & 0.039 & 1.30 & 0.010 & 0.023 & 2.39 \\
\hline Mugilids & 0.008 & 0.004 & 0.51 & 0.004 & 0.004 & 0.94 \\
\hline Annelids & 0.780 & 0.833 & 1.07 & & & \\
\hline Zoobenthos & 5.563 & 5.514 & 0.99 & & & \\
\hline Zooplankton & 2.044 & 2.282 & 1.12 & & & \\
\hline Molluscs & 3.489 & 3.618 & 1.04 & & & \\
\hline Phytoplankton & 2.625 & 2.556 & 0.97 & & & \\
\hline Phythobenthos & 11.474 & 11.266 & 0.98 & & & \\
\hline Detritus & 9.299 & 9.103 & 0.98 & & & \\
\hline Small mesh gillnets & & & 2.675 & 2.185 & 0.82 & \\
\hline Other gears & & & & 1.961 & 2.443 & 1.25 \\
\hline Total & 45.137 & 44.497 & 0.99 & 4.636 & 4.628 & 1 \\
\hline
\end{tabular}


Annex 1. Diet composition of functional groups for the model constructed.

\begin{tabular}{|c|c|c|c|c|c|c|c|c|c|c|c|c|c|c|c|c|c|c|c|c|c|c|c|c|c|c|c|c|c|c|c|c|c|c|c|c|}
\hline Prey \Predator & 1 & 2 & 3 & 4 & 5 & 6 & 7 & 8 & 9 & 10 & 11 & 12 & 13 & 14 & 15 & 16 & 17 & 18 & 19 & 20 & 21 & 22 & 23 & 24 & 25 & 26 & 27 & 28 & 29 & 30 & 31 & 32 & 33 & 34 & 35 & 36 \\
\hline 1 Sea cat fish & 0.01 & & & & & & & & & & & & & & & & & & & & & & & & & & & & 0.01 & & & & & & & \\
\hline 2 Neddlefish & & 0.01 & & & & & & & & & & & & & & & & & & & & & & & & & & & & & & & & & & \\
\hline 3 Pomfrets Torps & 0.01 & 0.02 & 0.02 & & & & & & & & & & & & & & 0.01 & & & & & & & & & & & & & & & & & & & \\
\hline 4 Bigeye scad & & 0.04 & 0.04 & & 0.01 & 0.01 & & & & & & 0.01 & & & & & 0.01 & & & & & & & & & 0.01 & & & 0.04 & & & & & & & \\
\hline 5 Yellowstripe & & 0.01 & 0.01 & & 0.01 & & & & & & & 0.01 & & & & & & & & & & & & & & & & & 0.01 & & & & & & & \\
\hline 6 Other Carangids & 0.03 & 0.11 & 0.10 & 0.01 & 0.02 & 0.04 & & 0.05 & & & & 0.01 & & & & & 0.02 & & & & & & & 0.10 & 0.08 & 30.05 & & 0.02 & 0.10 & & & & & & & \\
\hline 7 Milk fish & 0.01 & 0.01 & & & & & & & & & & & & & & & & & & & & & & & & & & & & & & & & & & \\
\hline 8 Wolf-herrings & & 0.03 & 0.03 & & 0.01 & & & & & & & 0.01 & & & & & & & & & & & & & 0.04 & 0.01 & & 0.01 & 0.03 & & & & & & & \\
\hline 9 Sardines & 0.01 & 0.04 & 0.04 & & 0.02 & 0.01 & & 0.12 & & & & 0.01 & & & & & & & & & & & & 0.03 & 0.04 & 0.02 & & 0.02 & 0.06 & & & & & & & \\
\hline 10 Herrings & 0.02 & 0.05 & 0.05 & & 0.02 & 0.03 & & 0.15 & & & & 0.01 & & & & & 0.01 & & & & & & & 0.10 & 0.10 & 0.05 & & 0.15 & 0.12 & & & & & & & \\
\hline 11 Other Clupeids & 0.01 & 0.02 & 0.01 & & 0.04 & 0.01 & & 0.04 & & & & 0.01 & & & & & 0.01 & & & & & & & 0.05 & 0.07 & 0.03 & & 0.04 & 0.07 & & & & & & & \\
\hline 12 Dolphinfishes & & & & & & & & & & & & 0.02 & & & & & & & & & & & & & & & & & & & & & & & & \\
\hline 13 Thrissa spp & 0.01 & 0.03 & 0.02 & & 0.01 & 0.02 & & 0.11 & & & & & & & & & 0.01 & & & & & & & 0.15 & 0.12 & 0.15 & & 0.19 & 0.12 & & & & & & & \\
\hline 14 Anchovies & 0.01 & 0.04 & 0.01 & & 0.05 & 0.03 & & 0.05 & & & & 0.01 & & & & & 0.01 & 0.03 & & & 0.02 & & & 0.15 & 0.11 & 0.16 & & 0.20 & 0.10 & & & & & & & \\
\hline 15 Flying fishes & & & & & & & & & & & & 0.01 & & & & & & & & & & & & & & 0.01 & & & & & & & & & & \\
\hline 16 Halfbeaks & & & & & & & & & & & & & & & & & & & & & & & & & & 0.02 & & & 0.02 & & & & & & & \\
\hline 17 False trevallie & & & 0.01 & & & & & & & & & 0.01 & & & & & 0.01 & & & & & & & & & 0.03 & & & 0.02 & & & & & & & \\
\hline 18 Ponyfishes & & & & & & & & 0.01 & & & & & & & & & 0.01 & & & & & & & & & & & & & & & & & & & \\
\hline 19 Mugilids & & & & & 0.01 & & & & & & & & & & & & & & & & & & & & & & & & & & & & & & & \\
\hline 20 Terabontids & & & & & & & & & & & & & & & & & 0.01 & & & & & & & & 0.01 & 0.02 & & & 0.03 & & & & & & & \\
\hline 21 Rit & & 0.01 & & & & & & & & & & & & & & & 0.01 & & & & 0.02 & & & & 0.02 & & & & 0.04 & & & & & & & \\
\hline $22 \mathrm{Drt}$ & & 0.01 & & & & & & & & & & & & & & & 0.01 & & & & & & & & 0.02 & 0.04 & & & 0.02 & & & & & & & \\
\hline 23 Ind.............. & & 0.03 & & & & & & & & & & 0.05 & & & & & & & & & & & & 0.02 & 0.03 & 0.01 & & 0.01 & 0.01 & & & & & & & \\
\hline 24 Small tunas & & 0.01 & & & & & & & & & & & & & & & & & & & & & & & & & & & & & & & & & & \\
\hline 25 Medium tunas & & & & & & & & & & & & & & & & & & & & & & & & 0.01 & 0.01 & & & & & & & & & & & \\
\hline 26 Large tunas & & & & & & & & & & & & & & & & & & & & & & & & 0.02 & 0.02 & 0.01 & & & & & & & & & & \\
\hline 27 Soles & 0.06 & 0.01 & & & 0.05 & & & & & & & & & & & & 0.05 & & & & 0.02 & & & & & & & & & & & & & & & \\
\hline 28 Large barracuda & & 0.01 & & & & & & & & & & & & & & & & & & & & & & & & 0.03 & & & & & & & & & & \\
\hline 29 Small barracuda & & 0.01 & & & & & & & & & & & & & & & & & & & & & & & & & & & 0.01 & & & & & & & \\
\hline 30 Shrimps & 0.02 & & 0.05 & 0.00 & & & & & & & & & & & & & 0.02 & 0.02 & & 0.05 & 0.04 & 0.04 & & 0.02 & 0.05 & 0.01 & 0.01 & & & & & & & & & \\
\hline 31 Crabs & 0.05 & & 0.01 & & 0.06 & 0.05 & & & & & 0.05 & 0.05 & & & & & 0.05 & 0.05 & & & & & & 0.05 & 0.02 & & & 0.01 & & & & 0.10 & & & & \\
\hline 32 Cephalopods & & & 0.01 & & & 0.25 & & 0.10 & & & & 0.05 & & & & & 0.10 & & & & 0.05 & & & 0.10 & 0.10 & 0.20 & & 0.10 & 0.05 & & & 0.10 & & & & \\
\hline 33 Molluscs & 0.06 & & & & 0.10 & & 0.02 & & 0.05 & 0.10 & 0.05 & 0.05 & & & & & & & & 0.05 & & & & & 0.04 & & & & & & 0.07 & 0.15 & & & & \\
\hline 34 Annelids & 0.15 & 0.05 & 0.05 & 0.02 & 0.10 & 0.05 & 0.15 & 0.02 & & & 0.05 & 0.05 & 0.10 & & & 0.02 & 0.10 & 0.15 & 0.02 & 0.05 & & & & & & & 0.10 & 0.01 & & 0.05 & 50.01 & & & & & \\
\hline 35 Zoobenthos & 0.30 & 0.25 & 0.20 & 0.06 & 0.35 & 0.35 & 0.25 & 0.25 & 0.10 & 0.05 & 0.61 & 0.35 & 0.25 & 0.20 & & 0.05 & 0.22 & 0.15 & 0.05 & 0.25 & 0.25 & 0.80 & 0.50 & 0.05 & 0.02 & 0.05 & 0.84 & 0.05 & 0.05 & 0.15 & 50.40 & 0.35 & & & 0.05 & \\
\hline 36 Zooplankton & 0.10 & 0.20 & 0.35 & 0.09 & 0.15 & 0.14 & 0.05 & 0.10 & 0.65 & 0.46 & 0.05 & 0.30 & 0.35 & 0.70 & 0.50 & 0.10 & 0.33 & 0.55 & 0.05 & 0.50 & 0.50 & 0.05 & 0.50 & 0.15 & 0.10 & 0.10 & 0.05 & 0.20 & 0.10 & 0.10 & 0.13 & 0.30 & & 0.05 & & 0.05 \\
\hline 37 Phytoplankton & & 0.01 & & & & 0.01 & 0.05 & & 0.20 & 0.39 & 0.04 & 0.01 & 0.05 & 0.10 & 0.50 & 0.20 & & & 0.60 & & & & & & & & & & & 0.10 & 0.01 & & & & 0.10 & 0.90 \\
\hline 38 Phythobenthos & 0.05 & & & 0.10 & & & 0.43 & & & & 0.10 & & 0.15 & & & 0.63 & & & 0.20 & 0.10 & 0.04 & 0.05 & & & & & & & & 0.20 & 0.03 & & 0.35 & 0.40 & 0.40 & \\
\hline $\begin{array}{l}39 \text { Detritus } \\
\text { Import }\end{array}$ & 0.10 & & & 0.72 & & 0.01 & 0.05 & & & & 0.05 & & 0.10 & & & & & 0.05 & 0.08 & & 0.06 & 0.06 & & & & & & & & 0.40 & 0.35 & & 0.65 & 0.55 & 0.45 & 0.05 \\
\hline Sum & 1.00 & 1.00 & 1.00 & 1.00 & 1.00 & 1.00 & 1.00 & 1.00 & 1.00 & 1.00 & 1.00 & 1.00 & 1.00 & 1.00 & 1.00 & 1.00 & 1.00 & 1.00 & 1.00 & 1.00 & 1.00 & 1.00 & 1.00 & 1.00 & 1.00 & 1.00 & 1.00 & 1.00 & 1.00 & 1.00 & 1.00 & 1.00 & 1.00 & 1.00 & 1.00 & 1.00 \\
\hline
\end{tabular}




\section{Figure captions}

Fig. 1. A map of the studied coastal ecosystem

Fig 2. The ECOPATH model for the coastal marine ecosystem of Sri Lanka indicating relative biomass of each group and the major flows connecting them. Less important flows are omitted for clarity sake. The horizontal axis of symmetry of each box is aligned with the trophic level of this box The value of a trophic level is a fractional because it depends on the diet composition of this group and on the trophic levels of its preys (Christensen and Pauly, 1993). B : Biomass B ( $\mathrm{km}^{-2}$ ), $\mathrm{P}$ : Production $\left(\mathrm{t} \mathrm{km}^{-2} \mathrm{yr}^{-1}\right)$, Q: Food consumption $\left(\mathrm{t} / \mathrm{km}^{2} \mathrm{yr}^{-1}\right)$. Arrows on the top of some box are actual catch. $\left(\mathrm{t} \mathrm{km}^{-2} \mathrm{yr}^{-1}\right)$.

Fig 3. A simulation of the possible effect of an El Niño event (which decreases the primary production by $50 \%$ for three months starting in May 1998) on abundance of key groups at various trophic levels. The seasonality in recruitment pattern was not considered.

Fig 4. The derived monthly mean catch rates (CPUE) for two ECOPATH functional groups: (a) Herrings (Period: January 1998 - December 2001) (b) Large tunas and kingfish (Period: January 1998 - December 2003). The trends in the CPUE obtained from the method of the moving average are also shown. 


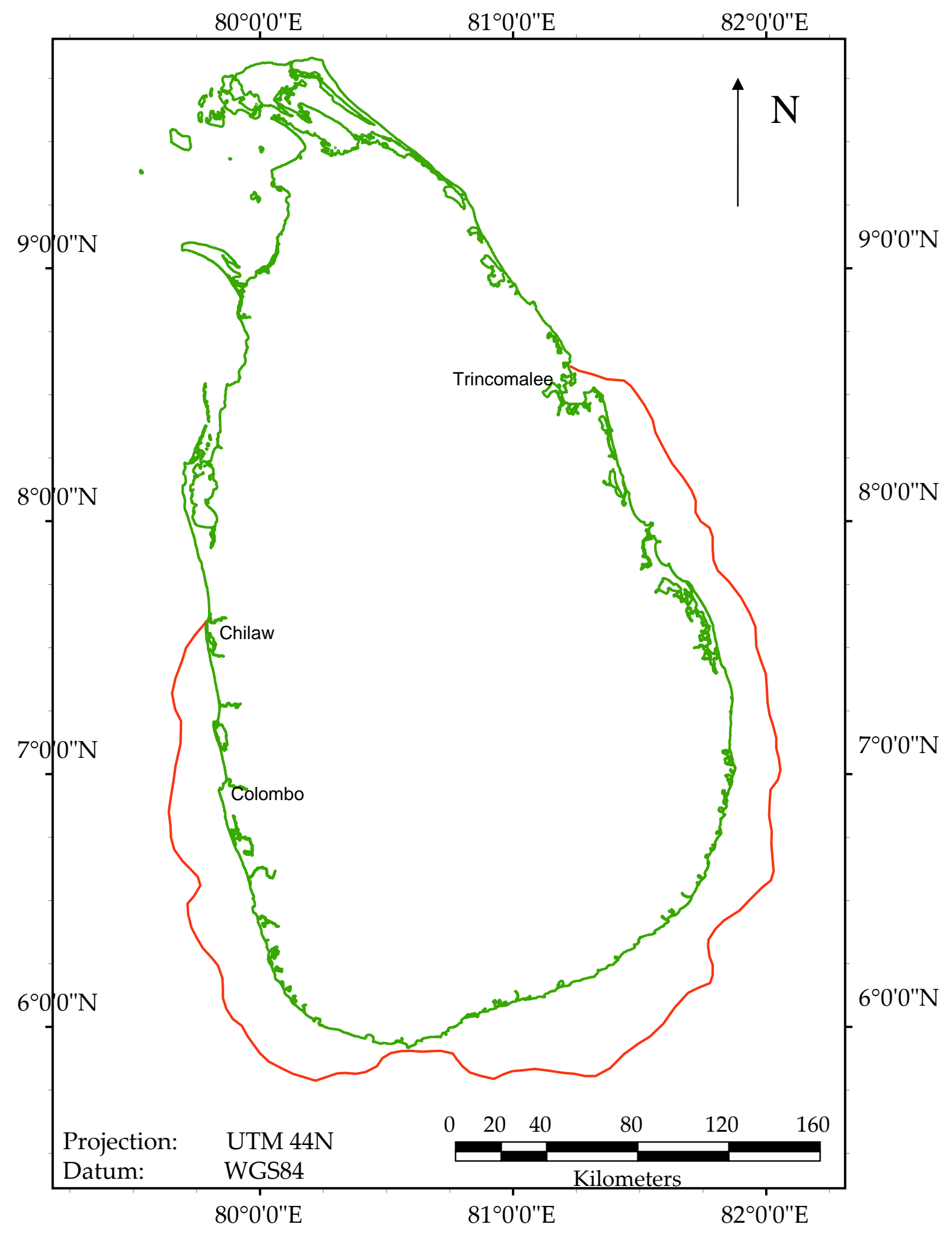




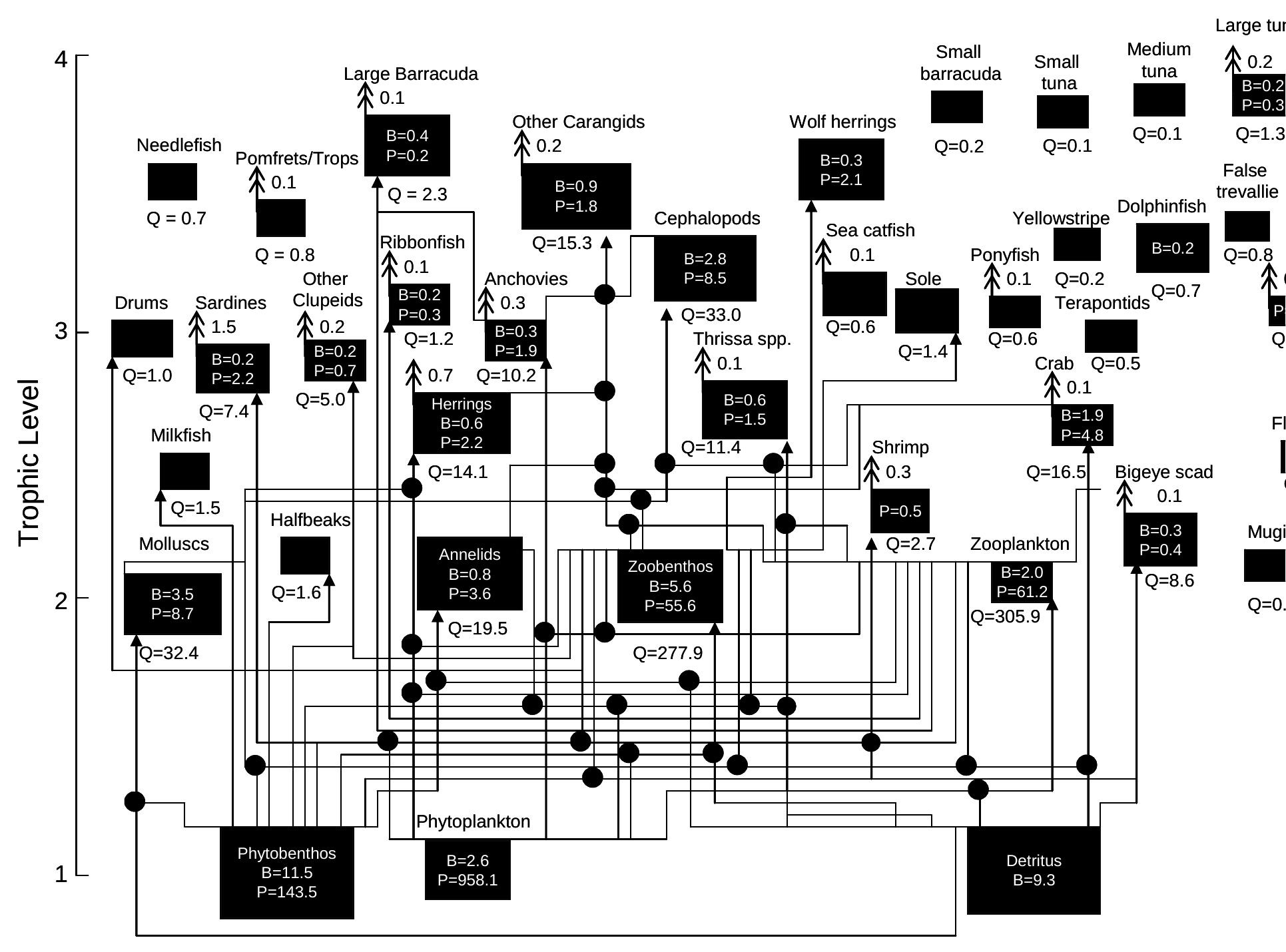



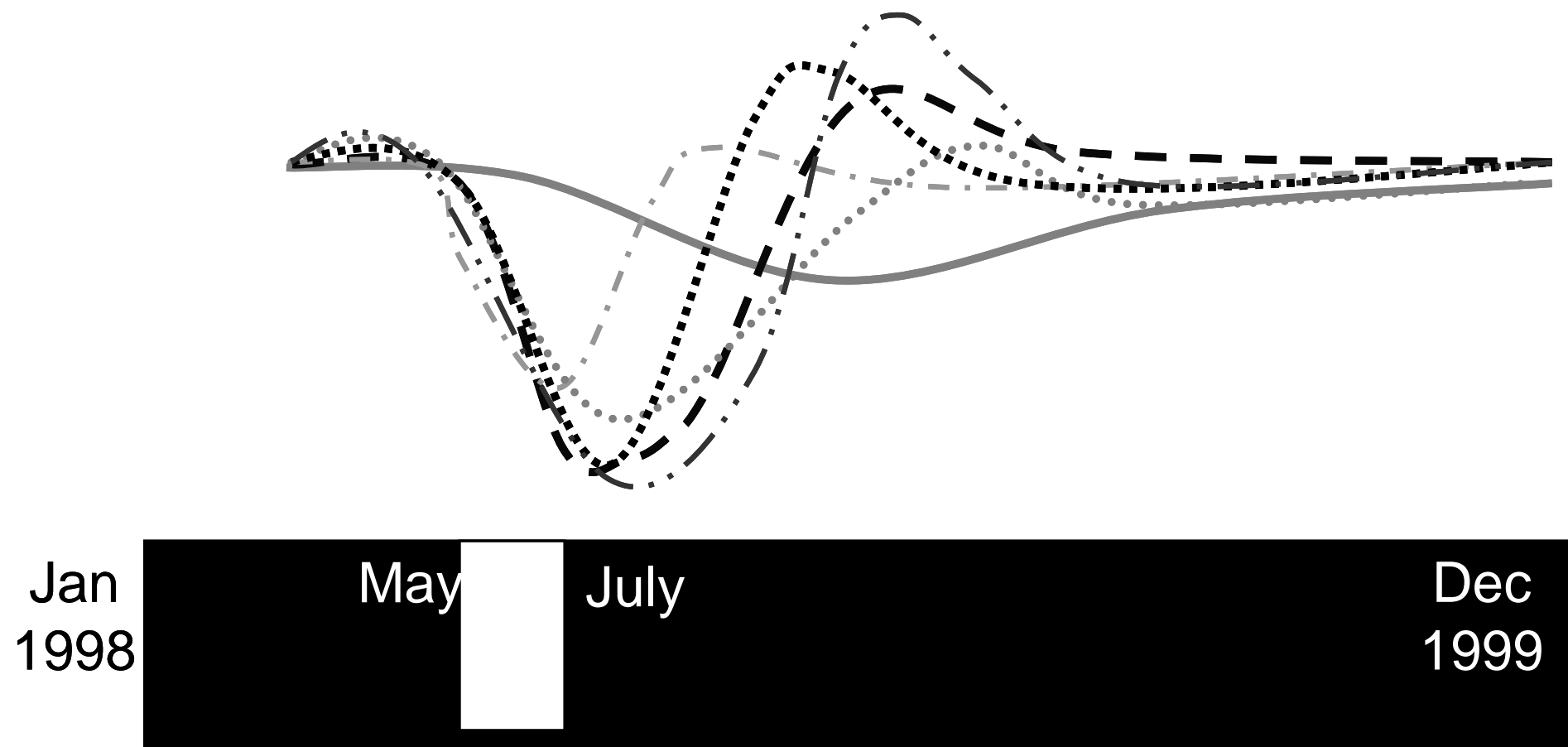

Dec
1999

-.-.- Phytoplankton

...... Zooplankton

-... Sardines
- - - Herrings

.... Anchovies

- Large tuna 


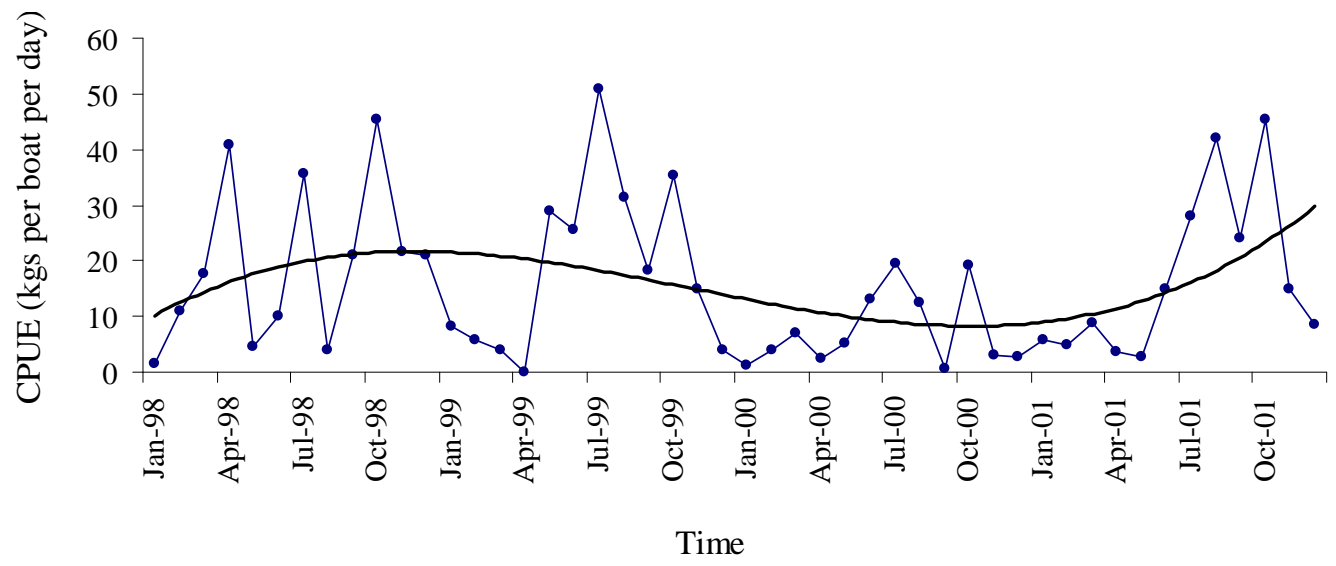

Figure $4 \mathrm{a}$ 


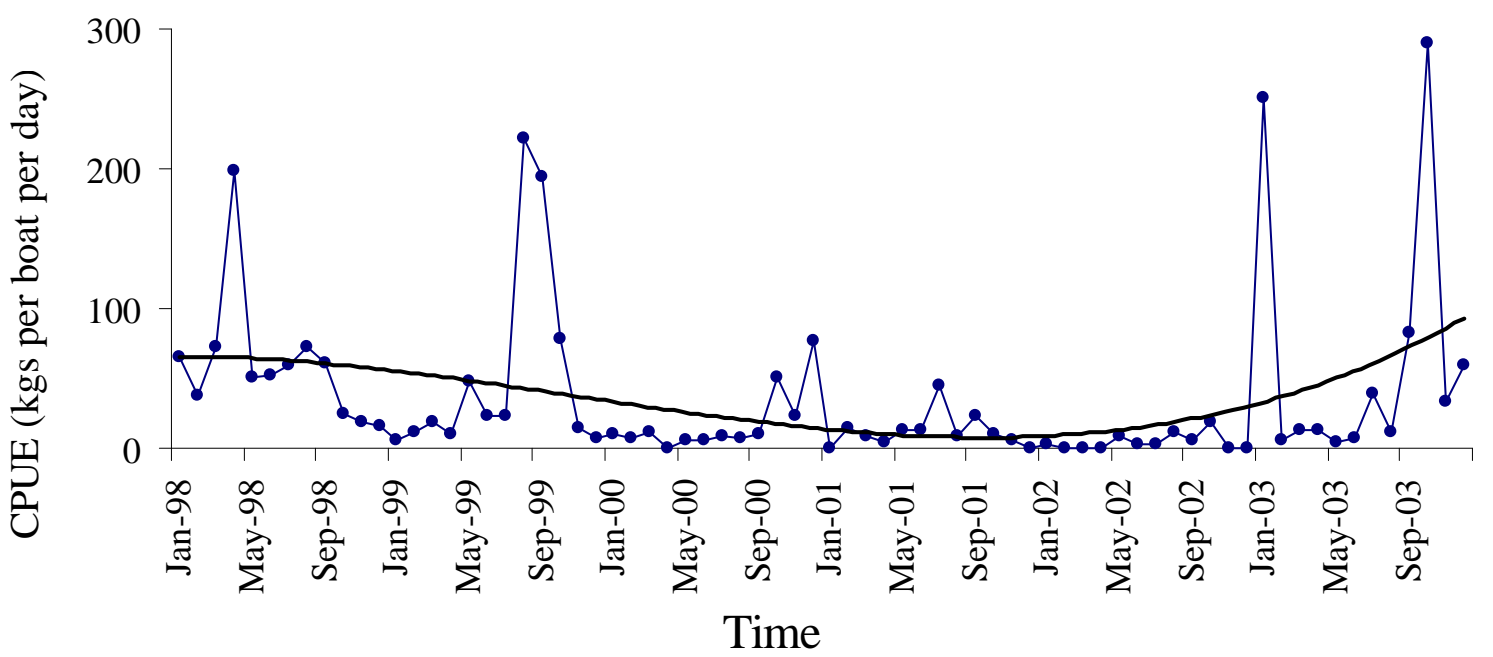

Figure $4 \mathrm{~b}$ 